\title{
Governance in Lebanese Banks: An Exploratory Research Before the COVID-19 Era
}

\author{
Hussin J. Hejase ${ }^{1}$, Ale J. Hejase ${ }^{2}$, Fatima Nemer ${ }^{3} \&$ Hassan Fayyad-Kazan ${ }^{4}$ \\ ${ }^{1}$ Senior Researcher, Prof. Business Administration, Beirut, Lebanon \\ ${ }^{2}$ AKSOB, Lebanese American University, Beirut, Lebanon \\ ${ }^{3}$ Faculty of Economics and Business Administration, Islamic University of Lebanon, Beirut, Lebanon \\ ${ }^{4}$ Faculty of Business Administration, Al Maaref University, Beirut, Lebanon \\ Correspondence: Hussin J. Hejase, Senior Researcher, Prof. Business Administration, Beirut, Lebanon. E-mail: \\ hhejase@gmail.com
}

Received: April 5, 2021

Accepted: May 5, 2021

Online Published: May 8, 2021

doi:10.20849/abr.v6i1.893

URL: https://doi.org/10.20849/abr.v6i1.893

\begin{abstract}
Banks locally and abroad have been subject to several financial crises which led top managers to look critically at their current practices in managing the financial resources in order to avoid losses and to prevent giving a negative image to the community of their customers. Parallel to the aforementioned events, banks have been observing an evolution of the banking investment activities in addition to the transformation of the financial market into an open market system.

The different events characterized by higher risks and higher demands for financial services have incited banks to explore and emphasize the importance of governance principles. In this study, the researchers will expose the importance of governance and its main principles in the banking systems. The study will also address the aforementioned pertinent to its implementation according to the activities of Basel Committee on banking supervision. The aim of the study is to assess via a quantitative approach the actual governance practices within a convenient sample of Lebanese banks. The outcomes show that the selected banks abide by the principles of Corporate Governance required by Basel as well as by the Central Bank of Lebanon. Results also address the effect of sound governance on the performance of the Banks in question. Findings will serve to issue recommendations about best practices and to encourage the adoption of sound decisions to adopt Corporate Governance principles.
\end{abstract}

Keywords: corporate governance, Basel Committee on Banking Supervision, the Lebanese banking sector

\section{Introduction}

Corporate governance has become one of the most important issues from 2002 up till today (Claessens and Yurtoglu, 2012, p. 2). It became important in many developed commerce and local regional organizations and foundations, after many financial fall downs, bankruptcy or merging of banks; also after numerous large financial scandals of top world firms like Enron, World Com and the world financial crises of 2008. These fall backs relate to problems in leadership, guidance, control, and fraud which lead to bankruptcy, loss of millions, and increase of unemployment. Moreover, "weaknesses in corporate governance structures within companies and banks were cited as reasons for excessive risk taking, skewed incentive compensation for senior managers, and the predominance of a board culture that values short-term gains over sustained, long-term performance" (ibid, p. 5). The aforementioned factors and the wrong application of governance led to financial corruption in banks and other financial institutions (Aidt, 2009; Nurhidayat \& Rokhim, 2018). This corruption leads to the lack of confidence in different financial markets and consequently the investors are drawn away $(\mathrm{Ng}, 2006)$. That is why there is an increasing interest in the concept of governance.

The Organization of Economic Cooperation and Development (OECD) has identified with the Center for International Private Enterprise (CIPE) to emit reports about governance in the different types of institutions including banks globally (CIPE, 2021; OECD, 2015). CIPE "strengthens democracy around the globe through private enterprise and market-oriented reform... CIPE's key program areas include enterprise ecosystems, democratic governance, business advocacy, and anti-corruption and ethics" (CIPE, 2021, para 1 and 2). It has been proved that developed countries have applied governance more rapidly than emerging countries (Hoskisson, Eden, Ming Lau, \& Wright, 2000). This study will provide a review about governance covering many aspects including 
stressing the importance of its application. Moreover, this study intends to explore and assess the status of governance application within the Lebanese banking sector.

The importance of the current study is in the effort to justify the need to apply the principles of corporate governance in the banking sector. Governance is a must as a result of the financial crisis and economic collapse as well as recent experiences in the world. The aforementioned negative symptoms led to find that weak governance systems in the banking institutions lead to vital and dangerous failures of the economy. Consequently, there should be intervention to protect the sector from the important problems, crises and collapses through the application of the principles of the Basel agreement to avoid and minimize risks that threaten the safety and stability of the banking sector. The application of the rules of corporate governance helps to improve the performance of the administration and protects the institution.

\subsection{The Objectives of This Research}

This paper highlights the concept of corporate governance in the banking sector and addresses its importance and benefits in order to improve quality and performance of the banks. It also clarifies the role of the Basel Committee and the Central Bank in establishing local standards and governance regulations. Finally, this paper exposes the actual governance practices of a sample of Lebanese banks.

\subsection{Problem Statements}

The current research intends to provide responses to the following problem statements:

- What is the importance of corporate governance in the banking sector?

- How much does applying governance standards of Basel Committee influence the banking sector?

- Does the banking sector apply governance with a greater effectiveness in Lebanon?

- Do the laws regulating corporate governance in Lebanon match recommended governance standards?

This paper is divided into five sections where the first addressed the background, objectives and research questions. The second section provides a brief literature review about the subject herein, while section three addresses the research methodology. Section four presents results and discussion to finish with section five with conclusions and recommendations.

\section{Literature Review}

\subsection{Governance Fundamentals and Principles}

The OECD (2004) introduces corporate governance as "one key element in improving economic efficiency and growth as well as enhancing investor confidence. Corporate governance involves a set of relationships between a company's management, its board, its shareholders and other stakeholders" (p. 11). While, the IFC (International Finance Corporation) identifies governance as "the system by which corporations are directed and controlled" (IFC, 2015, para 1). Further, Laeven and Ratnovski (2014, July 21) contend that corporate governance "is the practice of shareholders exercising control over managers so that they act in shareholders' interests" (Para 2). On the other hand, the Bank for International Settlements (BIS) (2015a) defines corporate governance as "a set of relationships between a company's management, its board, its shareholders and other stakeholders which provides the structure through which the objectives of the company are set, and the means of attaining those objectives and monitoring performance. It helps define the way authority is allocated and how corporate decisions are made" (p. 1). And the Institute of Chartered Accountants in England and Wales (ICAEW) (2016) declares that corporate governance is "the system by which companies are directed and controlled. Boards of directors are responsible for the governance of their companies. The shareholders' role in governance is to appoint the directors and the auditors and to satisfy themselves that an appropriate governance structure is in place" (Para 2).

\subsection{History of Governance Establishment}

The industrial revolution had a great effect on the investors which widened the establishment of many new corporations on one side, and on the other side, these investors had struggled with many conflicts to decide on the appropriate way that may lead to the separation of the ownership and management. This approach was called later: "Agency Theory" (Hamad, 2009). Namazi (2013) contends that "basic agency paradigm was developed in the economics literature during 1960s and 1970s in order to determine the optimal amount of the risk- sharing among different individuals" (p. 40). However, gradually the domain of the agency theory was extended to the management area for determining the cooperation between various people with different goals in the organization, and attainment of the goal congruency (Eisenhardt, 1989; cited in Namazi, 2013, p. 40). With time, more interest in establishing new systems and rules to organize the relationships among all partners. The 
aforementioned has enriched the interest in empowering the role as well as conception of governance. In fact, the New York stock market along with the National Association of Securities Dealers (NASD) have issued a report entitled "The Blue Ribbon Report" which discussed the effective role of the supervising committee at the corporations and the importance of complete commitment by the principles of institutional governance in 1999 . In the same year, OECD put forward a definition for governance and issued a number of flexible principles to facilitate applying governance which was revised in 2004 (Sleiman, 2009).

However, the year 2001 witnessed a clear increase of crashes and financial scandals in the monetary of many international corporations such as The WorldCom (Romero and Atlas, 2002) and Enron (Harvard Kennedy School (HKS), 2002) due to the occurring of trust crisis with the investors. The aforementioned cases led to the interference of the American government to make some adjustment in the norms of investment by which a suggestion was given by Senator Paul Sarbanes to establish a new law connected to governance and discusses the administrators' responsibility and speaks about the creation of independent committees to revise the transactions in the year 2002. According to an interview with Sarbanes, he says that the act has "brought about a marked improvement in corporate governance. It has eliminated a number of conflicts of interest and enabled our system of checks and balances to work as they should. It enables the watchdogs to be watchdogs" (Carozza, 2007, Para 5). Moreover, he adds that his intention with this legislation, "was to establish a good solid framework within which people could go about their business. We want them to do it in an honest and ethical way" (Para 7).

Dahya, McConnell, and Travlos (2002) contend that "in 1992, the Cadbury Committee issued the Code of Best Practice which recommends that boards of U.K. corporations include at least three outside directors and that the positions of chairman and CEO be held by different individuals. The underlying presumption was that these recommendations would lead to improved board oversight" (p. 461). It is to be noted that governance concept was founded in England in the year 1991 whereby the Cadbury committee was instituted by the London Stock Exchange to help corporations apply interior supervision which in turn reduces great losses. Sleiman (2009) asserts that the same committee also issued a report in the year 1992 entitled 'the financial statements of governed corporations" "to emphasize on the importance of corporate governance aiming to increase the investors trust in preparing the Financial Statements. The committee also forced the corporations to mention their commitment to the recommendations given by the committee" (pp. 17 - 18). Years later, the Financial Reporting Council, in the United Kingdom, put forward a document entitled 'The UK Corporate Governance Code' emphasizing the importance of corporate governance and stressing the key success factors of such governance in the UK (Financial Reporting Council (FRC), 2012).

\subsection{Importance of Governance}

According to Nasser (2008), the importance of governance manifests itself on many sides which benefit the concerned institutions including decreasing risk connected to corruption, gaining investors' trust, protecting investors' welfares and stakeholders, improving corporate performance and productivity, and helping prevent banking crisis from occurring.

The Financial Reporting Council (FRC) (2012), in the United Kingdom, believes that the benefit of governance is achieved by "facilitating effective, entrepreneurial and prudent management that can deliver the long-term success of the company" (p. 1). Several dimensions are affected namely, (1) Leadership, (2) Effectiveness, (3) Accountability, (4) Remuneration, and (5) Relations with shareholders.

\subsection{The Concept of Corporate Governance in Banks}

Mehran, Morrison, and Shapiro (2011) contend that previous to any analysis of governance in the banking sector, one must have an idea about "what is different about banks by asking what differences are important to governance?" (p. 1). In fact, Mehran et al. shed light on two themes- "the multitude of stakeholders in banks and the complexity of the business. However, besides shareholders, the stakeholders in banks are both numerous (depositors, debt-holders, and the government as both insurer of deposits and residual claimant on systemic externalities) and large (over 90 percent of the balance sheet of banks is debt). Yet shareholders control the firm, and evidence shows that both the boards and the compensation package for Chief Executive Officers (CEOs) represent the shareholders' preference for increasing risks. That preference, however, is in conflict with the preference of other stakeholders" (p. 1).

Many definitions exist. Sleiman (2009) posits that the Bank for International Settlements which controls the Basel committee, defines corporate governance in banks as "the principles used by the Board of Directors and the Top Management for the sake of managing the bank's business with the purpose of specifying the bank's goals and protecting the interest of the shareholders. That is to be accomplished with a complete commitment in accordance with the prevailing laws and regimes which will help achieve the security of investors' interests" (p. 
309).

Corporate governance is also a group of special methods and procedures that clarify the strategy followed by the board of directors and executive directors of various banking business and activities such as:

- Specifying strategically goals.

- Pursuing the ongoing of daily procedures.

- Applying their responsibilities towards people of interest.

- Making sure the bank's activities fit the laws and regulations (Sleiman, 2009, p. 309).

Governance is also defined as "the system by which banks are controlled and supervised on the purpose of achieving their goals and desires; it's the system used to organize the source of financial funds" (Abed Razak, 2009). While Sleiman (2009) defines governance in banks as "the observation of performance by the board of directors as well as the upper administration. It is concerned by protecting shareholders' rights equally to those of the investors'. In addition to that, it builds a good connection between those investors and shareholders with other outer members. A relation to be specified through a systematic form and the authority of the supervising committee" (p. 310).

Also, Han (2011) edited a regulatory document for the China Banking Regulatory Commission in which the term "corporate governance of commercial banks" is defined as "the relationships among general meetings of shareholders, Board of Directors, Supervisory Board, senior management, shareholders and other stakeholders. This specifically includes such check-and-balance mechanisms as the organizational structure, division of responsibilities and duty requirements, as well as such operating mechanisms as the decision-making, implementation, monitoring and incentives and disciplines" (Para 3).

On the other hand, according to the Bank for International Settlements (BIS) (2015a), "corporate governance determines the allocation of authority and responsibilities by which the business and affairs of a bank are carried out by its board and senior management" (p. 3). Different bank activities and affairs outlined by governance include: setting strategy and objectives, personnel management, daily operations, protecting stakeholders' interests, conserving the banks' integrity in compliance with laws and regulations, and setting control functions (BIS, 2015a, p. 3).

As for Lebanon, the Association of Banks in Lebanon (ABL) (2011) organized a conference in collaboration with the International Finance Corporation "IFC" on "Corporate governance for banks". Mr. Joseph Torbey, Chairman of ABL, contends that the purpose of the conference is "to identify in depth the foundations of the principles of good governance and to benefit from experience of international agencies in this area and experience some of the banks that have actually started to apply these principles in order to find what is most appropriate to the characteristics of our Lebanese banking sector in terms of business volume and the family nature" (Para 1). Furthermore, The Governor of the Banque du Liban (Central Bank of Lebanon), Mr. Riad Salameh said that "the central bank was aware of the dangers of the lack of governance rules, and issued several circulars from 2000 to activate the control mechanisms as well as the principles of good governance in banks and the formation of their boards" (ABL, 2011, Para 2). The Governor stressed that certain trends are considered based on several criteria including composition of the board and its representations, aligning the CEO or owner borrowing terms, controlling of the use of private funds of the bank and the adoption of diversity, update the Banks' statements of clients and their addresses for risk purposes, focusing on the role of auditors, and ensuring that standards and measures required by the BDL on the fight against money laundering are respected and applied (ABL, 2011, Para 3-9).

On the other hand, the Bank for International Settlements (BIS) which is the world's oldest international financial organization and having 60 member central banks representing countries from around the world that together make up about $95 \%$ of world GDP, asserts that "effective corporate governance is critical to the proper functioning of the banking sector and the economy as a whole. While there is no single approach to good corporate governance, the Basel Committee's revised principles provide a framework within which banks and supervisors should operate to achieve robust and transparent risk management and decision-making and, in doing so, promote public confidence and uphold the safety and soundness of the banking system" (Bank for International Settlements (BIS), 2015b, July, Para 1).

\subsection{The Importance of Corporate Governance at Banks}

Marcinkowska (2012) asserts that the global guidelines set by the Basel Committee for Banking Supervision are intended to improve corporate governance in banks. Therefore, good practices in corporate governance are important due to their positive impact on: "Supervisory board practices; senior management leadership; risk 
management and internal control; compensation policy; complex or opaque corporate structures; and disclosure of information and transparency" (p. 61). Moreover, Telekom Malaysia - TM (2014), uphold that "a strong corporate governance structure is crucial in ensuring continuous enhancement of shareholder value through financial performance while maintaining business sustainability, thus warranting continuing support of stakeholders" (p. 109).

\subsection{Governance Goals in Banks}

Claessens (2003) manifests that the literature has identified several channels through which corporate governance affects growth and development: (1) "The increased access to external financing by firms. This in turn can lead to larger investment, higher growth, and greater employment creation. (2) Lowering of the cost of capital and associated higher firm valuation. This makes more investments attractive to investors, also leading to growth and more employment. (3) Better operational performance through better allocation of resources and better management. This creates wealth more generally. (4) Good corporate governance can be associated with a reduced risk of financial crises. This is particularly important, as financial crises can have large economic and social costs. (5) Good corporate governance can mean generally better relationships with all stakeholders. This helps improve social and labor relationships and aspects such as environmental protection" (p. 14). Many goals help in implementing corporate governance. According to the Palestine Monetary Authority-PMA (2014), there are eight main goals including: maintaining monetary stability, protecting stakeholders' right, encouraging the flow of investment and development, facilitating access to optimum financial funding, increasing market confidence with all interested parties, reducing risks, and mitigate corruption (Palestine Monetary Authority-PMA, 2014, para 2-4).

\subsection{Significant Elements of Governance at Banks}

According to Abed Razzak (2009) and Lewis (2019), corporate governance addresses two kinds of corporate governance elements: Interior \& Exterior. Interior elements are the methods followed in decision making and distribution for the roles between the board of directors and the managers which help prevent the clash among contracting parties. The roles include: Shareholders, Board of directors, .Executive administration, and Interior Auditing. While external elements include: The juristic, observational and regulative field, Audience (Investors and Categorization corporations), and Mass media. On the other hand, Hartman and Slapničar (2007) addressed in their research the importance of internal governance as compared to external governance. They contend that, "external demands for efficiency in banks (external governance) should relate and translate to internal, organizational arrangements for performance management and incentive system design (internal governance). This is a crucial mechanism for ensuring higher efficiency and better financial performance, which will affect the risk-seeking behaviors of managers" (p. 6). Moreover, a member of the Association of Chartered Certified Accountants (ACCA) (2016) posits that, "Corporate governance can be seen as having internal and external sources, where external corporate governance consists of mandatory and voluntary codes, reports and frameworks such as company law, stock market listing rules and accounting and auditing standards. Internal corporate governance is how such external governance is complied with and embedded within the culture and values of the organization and how sound governance is implemented and works in practice" (Para 18).

\subsection{Governance of Banking Institutions and Principles}

Al Saidi (2004), Head of the Lebanese Corporate Governance Task Force, and through the proceedings of the second Middle East and North Africa Regional Corporate Governance Forum, posits that "progress has been achieved in the corporate governance of Lebanon's banking sector as a result of the application of international standards: the Basel I and II capital adequacy and the implementation of the Banking Control Commission and the Central Bank of Lebanon (Banque du Liban-BDL) of the Bank for International Settlements Core Principles for Effective Banking Supervision (Basel Committee Publications No. 30) as well as related prudential and regulatory measures (Basel Committee Publications No. 41), and Framework for Internal Control Systems in Banking Organizations (Basel Committee Publications No. 40)" (p. 42). Therefore, based on the above, this next section is dedicated to the review of the Basel committee and its role in the reinforcement of internal standards.

\subsubsection{Goals of the Banking Committee of Basel}

Bucur (2012) asserts that the banking area is under direct influence of the aggressive changes caused by the global economic situation in which it is evolving like the instability of interest rates, the increase of the competition, the concentration of the capital, etc..." (p. 75). However,

In 1987, the city of Geneva constituted the venue to start the effort to harmonize banking regulations, where an agreement was signed by the countries labeled "Group of 10 industrialized countries - G10 body. According to Bucur (2012), "the agreement aimed to establish the optimal size of the capital of a bank, the minimum level of 
the capital that a bank must have taken into account the size of the risks associated with its assets and the level of capital adequacy. This agreement is known as the "Basel Convention". One year later, concerns about the harmonization continued when in 1988 the Bank for International Settlements (BIS) proposed a minimum standard for capital adequacy. The proposed standard aimed to eliminate unfair competition and improved the protection of depositors (Bucur, 2012, p. 76).

The Basel Committee has been essentially established in order to achieve goals that serve the banking sectors (Abed Hamid, 2002-2003): "Reinforcing international banking system stability and performance; Banking supervising for the capital sufficiency; Creating methods to help the banks adapt with the technological development; and Developing observational strategies at the banks in order to ensure a worldwide stability" (pp. 82-83).

\subsubsection{Basel's Mission}

AdvisoryHQ (2016) asserts that the Basel Committee has two main reasons for proposing its Basel framework: "the first, to strengthen international banking by boosting their capital requirements, and the second, to remove inter-country competitive inequalities amongst G-10 banking institutions" (Para 18). Moreover, the BIS (1999) manifests that the Basle framework established "a structure that was intended to: (1) make regulatory capital more sensitive to differences in risk profiles among banking organizations; (2) take off-balance-sheet exposures explicitly into account in assessing capital adequacy; and (3) lower the disincentives to holding liquid, low risk assets" (p. 1).

\subsubsection{Basel's Decisions}

The Basel committee has issued two more treaties since its first in 1988 and its modified version in 1999 (Sleiman, 2006; BIS, 2015c, pp. 2-3.). The second treaty was issued in 2004 and then modified by 2006 (Ersel, 2011, Slide 10; BDL, 2008, Article 119; CFI, 2021a, para 1; BDL, 2006a, Article 2, p. 2), while the third was in the year 2010 (Bucur, 2012, p. 76; Claessens \& Kodres, 2014, p.8.).

Summarizing, Ersel (2011) believes that "Basel-I was hailed for incorporating risk into the calculation of capital requirements" (Slide 9). However, the author also posits that "Basel-I accord was criticized for taking a too simplistic approach to setting credit risk weights, and, for ignoring other types of risk" (Slide 22). According to Ersel (2011, slide 35) and CFI (2021, para 1), Basel-II accord consists of three pillars: "Minimum capital requirements for credit risk, market risk and operational risk — expanding the 1988 Accord (Pillar I); Supervisory review of an institution's capital adequacy and internal assessment process (Pillar II); and Effective use of market discipline as a lever to strengthen disclosure and encourage safe and sound banking practices (Pillar III)."

Moreover, BDL (2008) asserts that the most important recommendations of Basel regarding support three implementation are concluded in many essential cores: "Applying the appropriate disclosure in agreement with the international accounting standards; Rational importance of the intended disclosure topics; Qualification information specified by the banks; and The periodicity of disclosure" (Article 119).

\subsubsection{The Application of the Basel 2 Agreement in Lebanon}

After the issuance of the Basel 2 agreement, the Central Bank of Lebanon (BDL) obliged the banks to work actively and gradually on the application of this agreement as of January 1, 2008. It also identified the approaches to be adopted (BDL, 2006a).

Bucur (2012) asserts that "one of the prominent players in standardizing bank regulations across Europe was the "Banking Coordination Directive in Europe". Its role through the Basel accords defined the notion of "credit institution" by establishing the granting conditions for the authorization in the bank domain and creating the conditions for mutual recognition of authorization and banking supervision systems. Other major aspects were established of the banking activity, such as setting the minimum capital level for a bank" (p. 76). Moreover, Claessens and Kodres (2014) concur that the "informal group of regulators and central bank experts that had been meeting in Basel prior to the crisis became more formal in April 2009 through the establishment of the Financial Stability Board (FSB)" (p. 8).

According to the International Monetary Fund (IMF) (2019), "Basel III (2010) was a more far-reaching response to the lessons of the crisis, requiring banks to hold more, higher quality capital, introducing a leverage ratio and two new liquidity ratios. While the original 8 percent capital adequacy limit from Basel I and II was retained, effectively the minimum capital requirement became 10.5 percent of risk-weighted assets through the introduction of the capital conservation buffer" (Para 11). The reason behind the increase in capital \% lies is the fact that when the ratio is high, it indicates that the bank's ability to face crisis is high too since the increase in capitals is achieved by the profits. Add to this that employing private essential finance by such tools provides strength to funds base and a higher state of transparency towards stock markets, shareholders, investors and the 
like.

According to the Corporate Finance Institute (CFI) (2021b), "As of 2015, the Tier 1 capital requirement increased from $4 \%$ in Basel II to $6 \%$ in Basel III. The 6\% includes $4.5 \%$ of Common Equity Tier 1 and an extra $1.5 \%$ of additional Tier 1 capital. The requirements were to be implemented starting in 2013, but the implementation date has been postponed several times, and banks now have until January 1, 2022, to implement the changes" (Para 7).

\subsubsection{The Application of the Basel 3 Agreement in Lebanon}

In order to strengthen the solvency of the Lebanese banking sector so as to increase the effectiveness of capital in the face of shocks and absorb any unexpected losses and in implementation of the decisions of the Basel Committee on Banking Supervision in December 2010 about the solvency of banks under the Basel 3, the Central Bank has during the month of December 2011 adoption of new banking solvency rates and a timetable aims to raise solvency ratios in Lebanon, and it gradually until 2015 and at rates higher than those prescribed under the Basel 3.

\subsubsection{Governance Definition and Principles According to Basel}

BIS contends that governance is "a set of relationships between a company's management, its board, its shareholders and other stakeholders which provides the structure through which the objectives of the company are set, and the means of attaining those objectives and monitoring performance. It helps define the way authority and responsibility are allocated and how corporate decisions are made" (BIS, 2015b, July, p. 1).

\subsection{The Establishment of the Lebanese Banks Committee}

The banks' observation committee has been founded by the law 67/28 on the $9^{\text {th }}$ of May 1967; it is a separate committee of bank observatory that does not refer to the banks' authority in any mission practice. It consists of five members nominated by a decree- law taken by the council of ministers as a suggestion given by the minister of finance (BDL, 2021).

The committee's mission is to make sure the banking system written by loaning and currency law is well implemented. It also should make a regular addition to all banks and put a complete operatory system for any bank to improve its conditions or to control the bank's expenses and recommend the bank's commitment to those recommendations. The committee should also inform the Lebanese Central Bank's president with the general risks and the specified ones for each bank on the purpose of taking the appropriate systematic or observational arrangements (BCCL, 2021).

\subsubsection{Norms of Rational Banking Administration}

Globalization requirements and challenges brought about an international point of view to deal with risks and standardization. For such a purpose, the Basel committee was established by the Bank of International Settlements in 1974, with the job to help the banks and the assigned observational authorities, to issue the righteous recommendations and norms for the banking business and practices. The last of such recommendations was the document issued by Basel in November 2010 which included eight rules for rational banking administration depending on Basel's document by which all banks were asked to follow and implement those rules strictly. Exhibit 1 shows those principles and their requirements.

Exhibit 1. Basel eight rules for rational banking administration

Principle 1: Civil board members, capabilities and responsibilities (BDL, 2007, December 14, pp. 2-3).

Principle 2: Role of the Board in monitoring the strategic objectives of the bank (BDL, 2007, December 14, pp. 2-3).

Principle 3: Limits of responsibility and accountability (BDL, 2007, December 14, pp. 2-3).

Principle 4: Ensure supervision and monitoring by senior management (BDL, 2006b, March 9, p. 3).

Principle 5: Accounts and internal control monitors tasks (BDL, 2011b, April 21, pp. 3-6).

Principle 6: Salaries and bonuses the board of directors and executives (BIS, 2015b, July, p. 30).

Principle 7: Transparent governance (BIS, 2015b, July, p. 32).

Principle 8: Knowledge of the bank's operational structure 
Lebanon, through its Central Bank, recommended all Lebanese banks to abide by Basel recommendations. Circular No. 255 provides a summary of the recommendations which are depicted in Exhibit 2.

Exhibit 2. BDL Circular No. 255

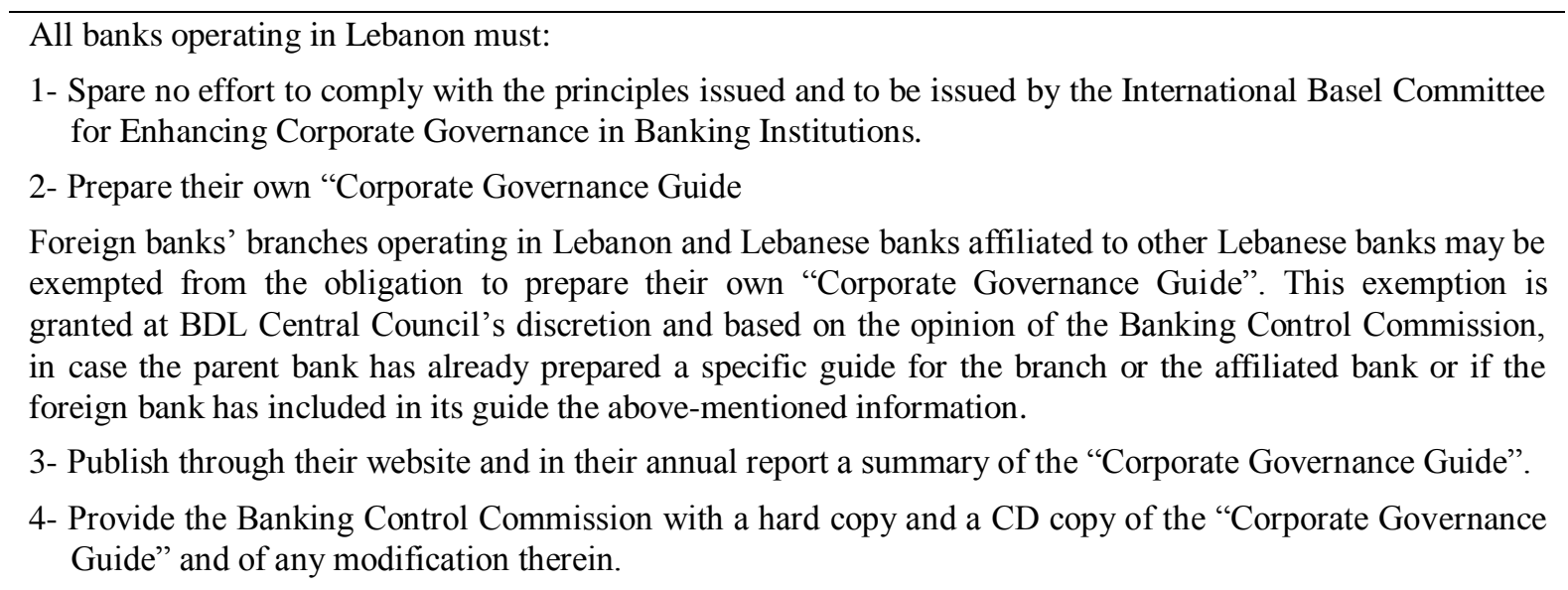

Source: BDL, 2011a, April 21.

According to the Central Bank of Lebanon (2000) in its Basic Circular no. 77, "the Senior Management must establish an internal control framework which is commensurate with the size of the bank or financial institution and the nature of the risks that any of them faces or may face; it must also update this framework when needed" (p. 3). The aforementioned framework must be based, at least, on the following components: internal environment, risks, internal control policies and procedures, complementary systems (accounting, risk assessment, archiving, and management of information), and continuous monitoring (BDL, 2000, December 15, p. 3).

\subsubsection{The Lebanese Banking Sector}

The association of Banks in Lebanon - ABL (2015) reports that the "Lebanese banking industry is financially sound and stable. It plays key roles in the Lebanese economy where banks continue to dominate the financial system of the country and are major providers of credit to individuals and businesses" (Para 1).

The bank regulatory authority, Bank of Lebanon (BDL), oversees the operations of all Lebanese Banks and other financial institutions and makes sure all these entities abide by national as well as international standards. "The Bank of Lebanon controls entry into the banking industry, defines the scope of banking activities and sets prudential regulations and codes of practice for banks" (ABL, 2015, Para 2).

Moreover, the Banking Control Commission (BCC), established in 1967, is the bank supervisory authority. It is responsible for supervising banking activities and ensuring compliance with the various financial and banking rules and regulations. Overall banking activities are also subject to both the Code of Commerce (1942) and the Code of Money and Credit (1963) (ibid, Para 3-4).

The progress realized by the Lebanese banking sector over the last ten years or so could not have been possible without the appropriate and strong bank regulation and supervision undertaken by the BDL and BCC and the close cooperation of the ABL.

\subsubsection{The Most Significant Characteristics}

According to the Association of Banks in Lebanon (ABL, 2015), the Lebanese banking field enjoys a state of stability and it also plays an essential role in the national economy that the banks are still controlling the financial system of the country for the reason that it is considered the largest financer for both individuals and corporations. Exhibit 3 depicts a brief summary. 
Exhibit 3. Lebanese Banking
1- There are a large number of banks of different sizes and formats.
2- Worldwide opening.
3- Human resources with high qualifications.
4- Providing up-dated and traditional services.
5- A sector committed to international standards.
6- A wide indulge in the Lebanese economy.
7 - Positive growth and performance.
8- A great ability to plan and embrace shocks and risks.

Source: ABL, 2015.

\subsubsection{How Lebanon Avoided Getting Affected by the Poisoning Drawbacks of International Crisis}

Advantage Consulting Company (2009) reported that "the Global Financial Crisis that broke out in 2007 and grew out of proportion through 2008 affected almost the every economy on the planet. We witnessed economies under immense strain to balance its affects, business giants going bankrupt, banks being nationalized and the various stimulus plans of governments to shield itself from lasting damage the crisis brought along" (p. 3). Furthermore, Finger \& Sdralevich (2009) report along the same topic, "But while many emerging market countries are deeply embroiled in the global economic crisis, the Lebanese economy could this year grow substantially faster than our recent conservative projection of 4 percent" (Para 1). Moreover, they added, "Lebanon has long looked highly vulnerable, and by the time the U.S. investment bank Lehman Brothers failed, Lebanon seemed a prime candidate for a textbook emerging market financial crisis" (Para 3). In fact, Advantage Consulting Company (2009) asserted that "Lebanon, which was best known for its wars, turmoil and instability, has not only been able to survive an economic crisis of global proportion, it has also thrived in it. During the times when the financial crisis hit the global businesses the hardest, Lebanese banks were posting record deposits while bankers claimed it to be the best year in Lebanon's financial history”' (p. 3).

Standard Chartered Bank organized a regional conference for the banks 'governors in the Middle East and North Africa (MENA) in Beirut, to discuss the Lebanese experience in surpassing the financial crisis. Riad Salameh, Lebanon's Central Bank governor, assured that Lebanon has always achieved a high capability financial policy during 17 years which is also characterized by its high effectiveness in facing both political and secular crisis which Lebanon has witnessed before the widespread of the international financial crisis.

The wise administration of the Lebanese Central bank followed a stable exchange rate for the Lebanese pound in order to face all economic difficulties and crisis which resulted in more trust in the Lebanese pound. The Lebanese solvency reaching 12\% in 2009 following Basel 2 recommendations \& Basel 3 which focuses on solvency and capital requirements. Mr. Salameh also announced that the Lebanese banks are totally ready to apply all of Basel's standards (Al Mal Wal Aalam, 2010).

\subsection{Risk Management}

\subsubsection{Definition of Risk Management}

Risk management embodies a comprehensive group of policies and strategies that aim at identifying expected events, assessing and forecasting possible risks in an attempt to measure those risks and quantify losses that might result in order to direct them for the sake of keeping them at minimum levels for any effective system of the rational banking. The success of this system is related in most situations to the existence of effective administration for the bank risks (BIS, 2011).

\subsubsection{Risk Management in Business}

Being exposed to risks is part of banking business but the exaggeration of risk holding or management deficiency or the inefficiency of its controlling systems may lead to certain losses that affect the bank's safety and its investors' trust or even their deposits (CFI, 2021c). According to observational authority of the Banking Control Commission-Lebanon, it is a must to guarantee a general administration of risk fighting ability that is up to date with the development of financial markets and those of activities, programs and services offered by the banks. The importance of risk management has been increased as it became an independent activity and an essential base of the rational banking administration (Banking Control Commission-Lebanon (BCCL), 2004, p. 
1).

The board of directors carries the final responsibility of risk management to attain the identified goals. The board should also agree on the general risk policy management including risk limits with entire kinds and reviewing it frequently (Lipton, Neff, \& Brownstein, 2019). The board also takes the suitable arrangements to improve risk management systems and increase their efficiency and competency by following the notes, suggestions and recommendations listed in the reports written by the observational committee on the banks and the observation of employees along with the interior investigation department at the bank as a result of each of those departments' performance. The board of directors usually establishes a risk committee to facilitate its mission in general risk management. This committee carries the mentioned responsibilities in addition to the direct supervision on the activity of risk management at the bank and observing the notes listed in the reports given by the risk management department (Banking Control Commission-Lebanon (BCCL, 2004, p. 2).

\subsubsection{Most Important Risks}

Many risks are put in the way of a number of banks which might be considered a source of danger to their financial and operational conditions that may affect their profits and even their continuity (Alem \& Associates, \& Étude Badri \& Salim El Meouchi, 2005, p. 6; BCCL, 2004, p. 1). Those risks can be classified into many essential groups such as: (1) Credit Risks; (2) Market Risks; (3) Operational Risks; (4) Liquidity Risks; and (5) Other or Residual Risks. On the other hand, Oberoi (2014) contends that "banks have to take risks all the time. Any bank has to take on risk to make money. This includes full-service banks, traditional banks, investment banks, or any other financial sector" (Part 4). Moreover, in addition to the first four risks discussed above, he added 4 more including: (5) Business risk; (6) Reputational risk; (7) Systemic risk; and (8) Moral hazard. "Out of these eight risks, credit risk, market risk, and operational risk are the three major risks. The other important risks are liquidity risk, business risk, and reputational risk. Systemic risk and moral hazard are unrelated to routine banking operations, but they do have a big bearing on a bank's profitability and solvency" (Oberoi, 2019).

Next, a brief description of some of the aforementioned risks.

1- Credit Risk: According to the Board of Governance of the Federal Reserve System (2021),

credit risk "arises from the potential that a borrower or counterparty will fail to perform on an obligation. For most banks, loans are the largest and most obvious source of credit risk. However, there are other sources of credit risk both on and off the balance sheet. Off-balance sheet items include letters of credit unfunded loan commitments, and lines of credit. Other products, activities, and services that expose a bank to credit risk are credit derivatives, foreign exchange, and cash management services" (Para 1).

2- Market Risk: King (2010) asserts that the "Basel Committee on Banking Supervision defines market risk as the risk of losses in on- or off-balance sheet positions that arise from movement in market prices" (p. 120). Moreover, Oberoi (2014, Part 6) classifies market risk as the most prominent for banks present in investment banking because they are generally active in capital markets. A number of market risks can be distinguished such as: Interest Rate Risk,

Equity Risks, Foreign Exchange Risk, Commodity Risk, Operational Risk, and Legal Risk.

3- Operational Risk:

Bank for International Settlements (BIS, 2011, June) defines operational risk "as the risk of loss resulting from inadequate or failed internal processes, people and systems or from external events. This definition includes legal risk, but excludes strategic and reputation risk" (p. 3). The kinds of Risk Operation include: Internal Process Risks, Business Risks, and Compliance Risks.

\section{Research Methodology}

Following the Onion Model criteria (Saunders, Lewis and Thornhill, 2009), the researchers assert a streamlined approach of the research process (Al Sayed, 2016, p. 51). This paper follows a quantitative research consisting of collecting, analyzing, interpreting, and writing the results of a study. "Quantitative researchers seek explanations and predictions with the intent to establish, confirm, or validate relationships and to develop generalizations that contribute to the theory under study" (Williams, 2007, p. 66). Quantitative research methods "involve using numbers and statistics in the research design based on a structured survey (Kothari, 2004, p.3; DeFranzo, 2011, Para 3).

Skinner, Edwards and Corbett (2015) contend that "quantitative research is used to test hypotheses, look at cause and effect, and make predictions" (p. 20). It uses statistics to generalize a finding and often reduces and 
restructures a complex problem to a limited number of variables. Therefore, the current research used quantitative research with the aim of using scientific methods in the assessment of the level of awareness and applicability of governance concepts in selected number of Lebanese banks.

\subsection{Research Philosophy}

This research is based on the principles of positivism. It depends on quantifiable observations that lead to statistical analysis (Collins, 2010, p. 38; Dudovskiy, n.d.). As indicated by Hejase \& Hejase (2013), research philosophy is the first issue to be taken into consideration for the researchers. It is the way of carrying out the research. "Positivism is when the researcher assumes the role of an objective analyst, is independent, and neither affects nor is affected by the subject of the research" (Hejase \& Hejase, 2013, p. 77; Crowther and Lancaster, 2008). Moreover, the positivist studies usually adopt a deductive approach (Crowther and Lancaster, 2008).

\subsection{Research Approach}

Having this research based on quantitative research method, then the approach followed is deductive with the aim "to test a previous theory in a different situation or to compare categories at different time periods" (Elo \& Helvi, 2008, p. 107).

Deductive approach can be explained by the means of hypotheses, which can be derived from the propositions of the theory (Wilson, 2010; Snieder and Larner, 2009, p.16). In other words, it is concerned with deducting conclusions from premises or propositions.

\subsection{Research Strategy}

Research strategy builds the roadmap for the research and forms the milestones in creating the research design. In fact, this paper deals with an unstructured problem and the researchers want to gain more knowledge about its characteristics. The researchers develop a literature review about the subject in section two to understand it. Hence, the research design is exploratory and uses a survey which includes creating a proper questionnaire and distributing it to individuals or companies face-to-face or via telephone, mail, or email (Hejase \& Hejase, 2013, pp. 114-115).

\subsection{Time Horizon}

The study is done at a particular point in time and it is not related to different periods. The data will be collected from respondents once and no comparison between dates is required. This type of research is called cross-sectional as stated by Hejase \& Hejase (2013, p. 79). Worth mentioning that data was collected in the period of February to April 2019, before the COVID-19 state of events (that was first reported from Wuhan, China, on 31 December 2019) and the aggressive negative state of events in Lebanon starting in October 2019.

\subsection{Data Collection Techniques}

Data collection included primary and secondary data. Secondary data was in the form of literature review which is considered as the logical starting point. The literature review was mainly used to provide a clearer image and understanding on the topic of this research. More than 30 references from books, scholar databases like EBSCO, and articles were reviewed to collect data, to understand better the problem of investigation and to illustrate different views on governance issues. On the other hand, the main tool of primary data used in this project is a quantitative survey questionnaire.

\subsection{Sampling}

\section{i. Target population}

The target population of the questionnaire is managers of different banks in Lebanon. The authors intended to cover as much as possible all of the bank sizes in order to formulate a general and holistic view on the status of governance applicability in Lebanese banks.

\section{ii. Sample selection and size}

This research used a non-probability sampling method for data collection, since the sample is accessible to the researchers. In fact, convenience sampling was used based on the fact that the respondents should be willing to participate and volunteer their time.

A cluster sampling will be made according to classification made by the Lebanese association of banks. Monthly (2018) listed a total of 65 Lebanese banks, however, according to MEAB (2019), there are 59 active total banks in Lebanon distributed as depicted in Table 1. 
Table 1. Total number of active Lebanese banks

\begin{tabular}{llll}
\hline Bank Category & Criterion & Number & Percentage, \% \\
\hline Alpha group & Alpha $>$ \$2B in Customer Deposits & 16 & 27.12 \\
\hline Beta group & Beta $\$ 500 \mathrm{M}<$ Customer Deposits $<$ \$2B & 15 & 25.42 \\
\hline Gamma group & \$200M $<$ Customer Deposits $<$ \$500M & 7 & 11.87 \\
\hline Delta group & Customer Deposits $<$ \$200M & 21 & 35.59 \\
\hline Total & & 59 & 100.00 \\
\hline
\end{tabular}

Based on the above, 11 banks are selected including three alpha, three beta, one Gamma, and four delta group banks. It is worth mentioning that the sample reached 11 survey respondents as the researchers faced very difficult times to convince more bank managers to participate either because of their heavy work load, or unwillingness, or not having clearance from the management.

The results of the questionnaire show that the sample chosen was diversified regarding demographic statistics and had sufficient knowledge on the research topic. Relying on convenience sampling has its pros and cons. Though it is faster, very cost-effective and convenient to the researchers, yet the data collected by this method may represent the view of a specific group and not the entire population. Consequently, inaccuracies are bound to creep in leading to high possibility of sampling error and conclusions drawn cannot be generalized.

\subsection{Questionnaire Design}

To reach the desired goal (the extent of the application of the rules of corporate governance in accordance with the principles of the Basel Committee on Banking in Lebanese banks and to clarify the impact on these banks), the researchers decided to use the survey questionnaire as the instrument to conduct the primary research. The survey consists of two parts:

- The first part includes questions on the subject of corporate governance in banks.

- The second part includes demographic questions or personal data (age, educational level, major, job description and number of years of service in the banking sector).

Therefore, the first part of the questionnaire design includes eleven sections covering the concepts depicted in Exhibit 4.

Exhibit 4. Questionnaire design part 1

\section{The basic responsibilities of the Board of Directors}

Consists of five statements intended to describe and assess the Board of Director's roles.

\section{The qualifications, independence, and formation of the members of the Board of Directors}

Consists of seven statements intended to describe and assess the Board of Director's choice criteria, development, qualifications, and duties.

\section{Practices of the Board of Directors, its structure, its committees, and conflict of interest}

Consists of seven statements intended to describe and assess the Board of Director's responsibilities, accountabilities, and performance evaluation.

\section{Good governance within a Group}

Consists of three statements intended to describe and assess the Board of Director's mode of application of organizational governance.

\section{Senior Management}

Consists of five statements intended to describe and assess the senior management's role and responsibilities.

\section{Risk Management Role}

Consists of seven statements intended to describe and assess how the Board of Directors deals with risk management in the bank. 


\section{Risk Management}

Consists of two statements intended to describe how the bank announces and encourages risk management.

\section{Using the results of the internal and external auditors and roles of internal control}

Consists of twelve statements intended to describe and assess how the Bank deals with internal and external auditing as well defining the auditors roles.

\section{Compensations}

Consists of three statements intended to describe how the bank deals with compensations.

\section{Knowing and understanding the structure of the bank}

Consists of four statements intended to describe how the bank deals with its structure and how the $\mathrm{BOD}$ and top management manage activities across the structure.

\section{Disclosure and transparency}

Consists of six statements intended to describe how the bank deals with disclosure and transparency.

Source: Researchers' work.

The researchers chose close-ended questions, such as five-level Likert scale questions, to offer respondents comfortability and ease of use as well as to ensure that all respondents take advantage of a formal and standardized form of questions which reflect their opinions. In order to ensure that the developed questions will return the required information, the researchers administered the questionnaire, as a pilot testing, on a sample of 3 bank manager respondents (who were not part of the research sample) and accordingly adjustments were applied to the questionnaire.

The questionnaire starts with a brief introduction which explains the purpose of the survey and assured the respect of the respondents' confidentiality.

\subsection{Quantitative Data Analysis}

Suitable statistical tools were used whereby, Hejase et al. (2012, p. 129) contend that informed objective decisions are based on facts and numbers, real, realistic and timely information. All responses were entered to the SPSS, version 23, program "Statistical Product and Service Solutions", a product acquired by IBM in 2009 (Hejase \& Hejase, 2013, p. 58). The study was performed using exploratory and descriptive statistics in the form of data tables including frequency and percentage distributions. Moreover, cross tabs were performed to study relationships between variables that may add value to the findings of the research.

\subsection{Research Ethics}

Bryman and Bell (2011) and Al Sayed (2016) contend that ethical issues arise at different stages in business and management research. Ethics cannot be ignored since it relates directly to the integrity of research and of the disciplines that are involved. Ethical concerns particularly arise in many areas including "harm to participants, informed consent, invasion of privacy, deception, data management, copy right, reciprocity and trust and affiliation \& conflict of Interest" (Bryman and Bell, 2011, pp. 128-142). All the research process activities of the current research including data collection, data analysis, and data presentation were consistent with the ethics principles and standards including the "principles of beneficence, fidelity, integrity, justice and respect for persons" (APA, 2017, pp. 3-4).

\section{Results and Findings}

The analysis of the resultant primary data follows the order of the questions as stated in the questionnaire design.

\subsection{The Basic Responsibilities of the Board of Directors (BOD)}

According to results, respondents representing the sample of Lebanese banks show a strong understanding of the responsibility of members of the Board of Directors (63.6\% strongly agree and 36.4\% agree), whereby, they stressed the strategic objectives, free access to perform corrective actions, and practicing effective and independent surveillance. However, to a lesser extent as measured by how strongly they agree on the statements (54.5\% strongly agree), they stressed the supervision function on top management $(45.5 \%$ agree) and less commitment to preserving shareholders and depositors' interests $(27.3 \%$ agree while $9.10 \%$ were either neutral or disagree). 


\subsection{The Qualifications, Independence, and Formation of the Members of the Board of Directors}

Results also show that the respondent managers believe that their Board of Directors are formed from reputable persons who show integrity (81.2\% strongly agree and $18.8 \%$ agree) and they also confirm that the BOD duties and responsibilities are specified with Rules \& Regulations (63.6\% strongly agree and 36.4\% agree). Moreover, respondents agree $(54.5 \%$ strongly agree and $45.5 \%$ agree) that there are audit and risk management committees and the BOD includes two independent members to guarantee impartiality. Furthermore, and with lower average agreement (36.4\% strongly agree and $63.6 \%$ agree), respondents believe that members of the BOD are selected based on experience, qualifications, and academic preparation. Respondents showed lowest degree of agreement and higher neutrality when they were asked if BOD members are trained with courses and workshops to boost efficiency and governance.

\subsection{Practices of the Board of Directors, Its Structure, Its Committees, and Conflict of Interest}

Seven statements are assessed. Table 2 shows that $90.9 \%$ of the respondents agree $(36.40 \%$ strongly agree and $54.5 \%$ agree) that their Board of Directors set clear and specific limits for themselves and for all the bank managers and employees pertaining to their responsibilities and ranges of accountability.

Table 2. Practices of the Board of Directors, its structure, its committees, and conflict of interest

\begin{tabular}{lllll}
\hline Statement & SA & A & N & D \\
\hline The BOD set clear limits of responsibility and accountability to all & 36.4 & 54.5 & 9.1 & \\
\hline Establishing a Management structure to promote accountability \& Responsibility & 54.5 & 27.3 & 18.2 & \\
\hline The BOD conducts periodic evaluations & 36.4 & 18.2 & 27.2 & 18.2 \\
\hline Applying good governance & 63.6 & 27.3 & 9.1 & \\
\hline President of BOD takes appropriate decisions after discussions & 63.6 & 27.3 & 9.1 & \\
\hline The BOD ensures Policies exist to reduce conflict of interest & 54.5 & 27.3 & 18.2 & \\
\hline The BOD members assigned in collaboration with influential stakeholders & 36.4 & 27.3 & 27.3 & 9.1 \\
\hline
\end{tabular}

Table 2 confirms the previous results by showing that there is also an established banks' management structure to promote the appropriate accountability and the clear definition of responsibilities. Moreover, $54.6 \%$ of the respondents agree that their Board of Directors through an executive council conducts periodic evaluation of all employees, in group and individually, in order to achieve improvement and applying the appropriate corrective actions where needed. Furthermore, $90.9 \%$ of the Board of Directors constantly and regularly apply good corporate governance practices, a fact highly needed to comply with the Central Bank requirements as well as with Basel standards.

Also, results show that $90.9 \%$ of the respondents agree (63.6\% strongly agree, $27.3 \%$ agree and $9.1 \%$ neutral) that the president of the Board of Directors takes appropriate decisions after discussions having in mind the Bank's benefits; $81.8 \%$ of the respondents agree (54.5\% strongly agree, $27.3 \%$ agree and $18.2 \%$ neutral) that the banks' Boards of Directors ensure that appropriate policies exist to reduce any conflict of interest; and $63.7 \%$ of the respondents agree (36.4\% strongly agree, $27.3 \%$ agree; $27.3 \%$ neutral and $9.1 \%$ disagree) that the banks' members of the Board of Directors are assigned in collaboration with influential stakeholders.

\subsection{Good Governance Within the Group}

Findings show the respondents inputs on three statements related to governance application within the banking group. $100 \%$ of the respondents agree (45.5\% strongly agree \& $54.5 \%$ agree) that the BOD applies good governance across the group; while $90.9 \%$ agree $(72.7 \%$ of strongly agree \& $18.2 \%$ agree) that there exists a suitable structure for governance to assure effective supervision (9.1\% were neutral); also $100 \%$ of the respondents agree (63.6\% strongly agree and $36.4 \%$ agree) that their BODs use suitable surveillance means for compliance and good governance within the group.

\subsection{Senior Management}

Results also show the respondents inputs on five statements related to top management including the BOD and senior managers and their role in applying the Banks' strategies. $72.8 \%$ of the respondents agree $(45.5 \%$ strongly agree and $27.3 \%$ agree) that the terms of reference for BOD are varied for an effective role in management of the 
banks' daily activities while, $9.1 \%$ are neutral, and $9.1 \%$ disagree; All of the respondents agree on several facts including that their BODs represent good examples in the bank and consequently it is reflected in the productivity of the bank; that their senior managers assure the bank compliance to the set strategies; that their senior managers are able to handle risk. Finally, 45.5\% of the respondents believe that their senior managers monitor the banks' performance by monitoring the BOD's performance, $18.2 \%$ agree, $9.1 \%$ are neutral and $9.1 \%$ disagree.

\subsection{Risk Management Role}

Table 3. Risk management roles

\begin{tabular}{lllll}
\hline Statement & SA & A & N & D \\
\hline The BOD deals with risk as most important priority & 36.4 & 18.2 & 36.4 & 9.1 \\
\hline The BOD appoints independent commission to minimize losses & 27.3 & 63.6 & 9.1 & \\
\hline The bank respects BDL decisions and risk management & 81.8 & 18.2 & \\
\hline $\begin{array}{l}\text { The Risk Management Committee identifies surveillance \& reporting of risk } \\
\text { ratio }\end{array}$ & 81.8 & 18.2 & \\
\hline $\begin{array}{l}\text { The Risk Management Committee has complete freedom to take info as } \\
\text { needed }\end{array}$ & 72.7 & 18.2 & 9.1 \\
\hline The Risk Management Committee possesses required qualifications & 54.5 & 45.5 & \\
\hline The Director of Risk Management Committee holds one position & 54.5 & 27.3 & 18.2 \\
\hline
\end{tabular}

Results from Table 3 show the respondents inputs on seven statements related to top management's role to deal with risk management. All respondents agree that their bank respects BDL decisions and risk management; that the Risk Management Committee identifies surveillance \& reporting of risk ratio; and that the Risk Management Committee possesses required qualifications including the BOD and risk management committee. Moreover, $54.6 \%$ of the respondents agree (36.4\% strongly agree and $18.2 \%$ agree) that BOD deals with risk as top priority while $27.3 \%$ are neutral, and $9.1 \%$ disagree; $90.9 \%$ of the respondents also agree $(72.7 \%$ strongly agree and $18.2 \%$ agree) that the Risk Management Committee has complete freedom to take information as needed but 9.1\% are neutral; and finally, $81.8 \%$ of the respondents believe that the Director of Risk Management Committee holds only one position, (54.5\% strongly agree and $27.3 \%$ agree), and $18.2 \%$ are neutral.

\subsection{Risk Management}

Two statements assess this dimension. The first statement "Bank's risk ratio \& its strategy are known to all branches" shows that $72.8 \%$ (45.5\% strongly agree and $27.3 \%$ agree) of the respondents agree and confirm that the Bank's risk ratio and its strategy are known to all branches, $9.1 \%$ are neutral while $18.2 \%$ disagree. The second statement shows that $63.6 \%$ of the respondents agree $(27.3 \%$ strongly agree and $36.3 \%$ agree) that their banks encourage setting up an independent committee to manage risk, $18.2 \%$ are neutral, and $18.2 \%$ disagree.

4.8 Using the Results of the Internal and External Auditors and Roles of Internal Control

Table 4. Using the results of the internal and external auditors and roles of internal control

\begin{tabular}{lllll}
\hline Statement & SA & A & N & D \\
\hline Bank has an Internal Audit unit & 72.7 & 27.3 & & \\
\hline Bank Internal Audit is independent & 63.6 & 18.2 & 9.1 & 9.1 \\
\hline Bank Internal Audit Process is ran on regular basis & 54.5 & 36.4 & 9.1 & \\
\hline Bank Internal Audit is regulated with laws and policies & 54.5 & 45.5 & & \\
\hline Internal Auditors are qualified (efficient, experienced and quality work) & 54.5 & 45.5 & & \\
\hline Internal Auditors pledge to disclose all financial facts reached & 36.4 & 36.4 & 18.2 & 9.1 \\
\hline Internal Auditors pledge not to exploit info for personal benefit & 54.5 & 36.4 & 9.1 & \\
\hline
\end{tabular}




\begin{tabular}{llll}
\hline Internal Auditors comply with Local \& International Standards & 81.8 & 9.1 & 9.1 \\
\hline Internal Auditors respect confidentiality of Information & 90.9 & 9.1 & \\
\hline Internal Auditors monitor employees with key positions & 54.5 & 18.2 & 27.3 \\
\hline Audit results are used effectively to address weaknesses & 81.8 & 18.2 & \\
\hline External Auditors are Independent and Efficient & 81.8 & 9.1 & 9.1 \\
\hline
\end{tabular}

Table 4 shows the respondents inputs on twelve statements related to internal and external auditors and the role of internal auditing. All respondents agree that their banks have an internal audit unit that is regulated with laws and policies; that their internal auditors respect confidentiality of information; that the selection of internal auditors is based on specific qualifications; and that audit results are used effectively to address weaknesses. Moreover, $81.8 \%$ of the respondents agree $(63.6 \%$ strongly agree and $18.2 \%$ agree) that the internal audit unit is an independent entity to assure objectivity. Also, $90.9 \%$ of the respondents $(54.5 \%$ strongly agree and $36.4 \%$ agree) that the internal audit unit runs on a regular basis.

As for the practices, $72.8 \%$ of the respondents agree that the bank's internal auditors pledge to disclose all financial facts reached, $18.2 \%$ are neutral and $9.1 \%$ disagree. Most probably such act is governed by the specific bank's policies. Further, it is a fact that the role of the internal auditor is not to exploit information for personal benefits whereby $90.9 \%$ agree and $9.1 \%$ are neutral about the issue. $90.9 \%$ of the respondents agree that internal auditors follow local and international standards a fact that reflects that the Lebanese banks abide by the Central Bank's decrees and follow Basel agreements requirements.

Moreover, $72.7 \%$ of the respondents agree that internal auditors monitor key personnel in their banks and $27.3 \%$ are neutral.

\subsection{Compensations}

Further results show that $72.7 \%$ of the respondents agree that their BODs ensure wages and reward policies fit the culture and the banks' strategic plans, while $18.2 \%$ are neutral. $54.5 \%$ of the respondents agree that the banks' incentives for Senior Managers and Executive Managers meet banks' long-term commitments, while $27.3 \%$ are neutral and $18.2 \%$ disagree. It looks like in this statement, not all respondents feel fairness in terms of their compensations. Further, $72.7 \%$ of the respondents agree that the banks' compensations are calculated based on emerging risk results after years, while $18.2 \%$ are neutral and $18.2 \%$ disagree. Respondents in this statement do not fully agree that compensations are calculated as specified.

\subsection{Knowing and Understanding the Structure of the Bank}

The respondents' inputs on four statements related to risk and the banks' structures were as follows: $90.9 \%$ of the respondents (63.6\% strongly agree and $27.3 \%$ agree) that their BODs manage the banks with effectiveness to avoid any legal risks, $9.1 \%$ are neutral. $90.9 \%$ of the respondents $(81.8 \%$ strongly agree and $9.1 \%$ agree) that Senior Managers have surveillance on Bank activities to prevent illegal risks, while $9.1 \%$ are neutral. Moreover, all respondents agree that their banks have clear structures that comply with adopted policies and strategies. Finally, $81.8 \%$ of the respondents (63.6\% strongly agree and $18.2 \%$ agree) that centrality is adopted when approving and supervising the establishment of affiliated new institutions, while $18.2 \%$ are neutral about the issue.

\subsection{Disclosure and Transparency}

Table 5. Disclosure and transparency

\begin{tabular}{llll}
\hline Statement & SA & A & N \\
\hline Bank discloses all info about activities \& operations & 36.4 & 54.5 & 9.1 \\
\hline Disclosure includes info related to substantial risks & 36.4 & 36.4 & 27.4 \\
\hline The BOD discloses info about established committees & 54.5 & 36.4 & 9.1 \\
\hline The administration discloses accounting policies about bank risks & 36.4 & 45.5 & 9.1 \\
\hline The bank considers the External Auditor notes about financial statements & 54.5 & 36.4 & 9.1 \\
\hline Disclosure must be clear, understandable, and accurate & 63.6 & 27.3 & 9.1 \\
\hline
\end{tabular}


Table 5 shows the respondents inputs on six statements related to disclosure and transparency practices in the banks. The grand majority or $90.9 \%$ of the respondents agree on five of the six statements including: banks disclose all information about activities and operations; the BOD discloses information about established committees; the administration discloses accounting policies about bank risks; the bank considers the External Auditor notes about financial statements; and disclosure must be clear, understandable, and accurate. However, $72.8 \%$ of the respondents agree that the disclosure includes information related to substantial risks, while $37.2 \%$ are neutral.

\subsection{Sample Demographics}

According to results, respondents are $72.7 \%$ males and $27.3 \%$ females; $45.5 \%$ of the respondents belong to the age group $>50$, followed by $27.3 \%$ for the age group ranging [41 - 50]. The first age group >30 was 18.2; $54.5 \%$ of the respondents have a master degree, $27.3 \%$ carry a bachelor degree, and finally an equal $9.1 \%$ hold a $\mathrm{PhD}$ degree or did not earn a bachelor degree. Moreover, $36.4 \%$ of the respondents are currently working as General Managers and another $36.4 \%$ occupying other executive positions. Moreover, $9.1 \%$ occupy an internal auditing position and $18.2 \%$ are branch managers. Also, $45.4 \%$ of the respondents have more than 15 years of experience, followed by $36.4 \%$ who have between $\{11-15\}$ years, and another $9.1 \%$ who have $\{5-10\}$ years of experience.

\subsection{Crosstabs}

Descriptive statistics were performed in the previous sections and results were manifested using frequency and probability distribution tables. In this section the researchers present the outcomes of performing cross tabulations between the variables.

According to Hejase \& Hejase (2013), "a contingency table is a data matrix or a cross-tabulation that simply organizes nominal, ordinal or classes of data by groups to form a joint frequency distribution" (p.295). Therefore, the next step is to construct cross-tabulations of possible relationship which may help analyze the respondents' inputs. However, as data was analyzed, and taking into account Shier's (2004) validity observation stating that "Chi-squared tests are only valid when you have a reasonable sample size. The following guidelines can be used:

For 2 x 2 tables:

- If the total sample size is greater than $40, \chi^{2}$ can be used.

- If the total sample size is between 20 and 40 and the smallest expected frequency is at least $5, \chi^{2}$ can be used.

- Otherwise Fisher's exact test must be used" (p. 2).

Furthermore, Mehta and Patel (2012) from IBM, contend that "the Exact Tests option provides two new methods for calculating significance levels for the statistics available through the Crosstabs and Nonparametric Tests procedures" (p.1). Moreover, according to the authors, "these new methods, the Exact and Monte Carlo methods, provide a powerful means for obtaining accurate results when the data set is small, the tables are sparse or unbalanced, the data are not normally distributed, or the data fail to meet any of the underlying assumptions necessary for reliable results using the standard asymptotic method" (p. 1).

\section{Crosstabs: Using the Exact Tests Options}

Having a sample of 11 banks represented by 11 executive managers, leads to the use of Exact Tests, namely the Fisher Test. Tables 6, 9 and 10 herein depict the results for the rejected / accepted hypotheses testing independence of variables.

Table 6. Exact Tests Options: [Null hypothesis that the two variables are independent, $\alpha=5 \%$ ]; Rejection cases

\begin{tabular}{llc}
\hline Crosstab & $\begin{array}{l}\text { Fisher Exact } \\
\text { Sig. (2-sided) }\end{array}$ & Decision \\
\hline $\begin{array}{l}\text { Crosstab 1: "The BOD approves and supervises Bank's Strat Obj. * The BOD } \\
\text { performs an effective and independent surveillance" }\end{array}$ & $.003<.05$ & Rejected \\
\hline $\begin{array}{l}\text { Crosstab 4: "The BOD approves and supervises Bank's Strat Obj. * The BOD } \\
\text { supervises top management performance" }\end{array}$ & $.015<.05$ & Rejected \\
\hline $\begin{array}{l}\text { Crosstab 5: "The BOD approves and supervises Bank's Strat Obj. * The BOD form } \\
\text { committees: Audit \& Risk" }\end{array}$ & $.015<.05$ & Rejected \\
\hline Crosstab 16: "The BOD approves and supervises Bank's Strat Obj * Bank has clear & $.024<.05$ & Rejected \\
\hline
\end{tabular}


structure that complies with policy \& strategy adopted"

Crosstab 18: "The BOD performs an effective and independent surveillance of the $.015<.05 \quad$ Rejected bank * The BOD supervises the performance of senior management"

Crosstab 19: "The BOD has free access to information to do corrective action" * $.003<.05 \quad$ Rejected President of BOD takes appropriate decisions after holding important discussions for the benefit of the bank"

Crosstab 22: "Applying good governance * Suitable structure for governance to assure $\quad .012<.05 \quad$ Rejected effective supervision"

\begin{tabular}{llll}
\hline Crosstab 23: "The BOD behavior reflects productivity of the bank * The BOD applies & $.015<.05$ & Rejected \\
good governance for the group as a whole" & & \\
\hline $\begin{array}{l}\text { Crosstab 25: "Internal Auditors are qualified (efficient, experienced and quality work) } \\
* \text { Internal Auditors pledge to disclose all financial facts reached" }\end{array}$ & & Rejected \\
\hline $\begin{array}{l}\text { 26 Crosstab 26: "The BOD ensures wages and reward policies fit culture \& bank's strat } \\
\text { plans * Incentives for Senior Managers and Executive Managers meet bank's }\end{array}$ & & \\
long-term goals & & & \\
\hline $\begin{array}{l}\text { Crosstab 29: "Disclosure includes information related to substantial risks the bank is } \\
\text { exposed to * Bank discloses all info about activities \& operations" }\end{array}$ & & \\
\hline
\end{tabular}

For the sake of clarity, Crosstab 1 and Crosstab 2 are included herein to provide an explanation of the analysis of results whereby the hypotheses for independence were either rejected or accepted.

Crosstab 1: "The BOD approves and supervises Bank's Strat Obj. * The BOD performs an effective and independent surveillance"

Table 7. Chi-Square Test for Crosstab 1

\begin{tabular}{|c|c|c|c|c|c|c|}
\hline & Value & df & $\begin{array}{c}\text { Asymptotic } \\
\text { Significance } \\
\text { (2-sided) }\end{array}$ & $\begin{array}{c}\text { Exact Sig. } \\
\text { (2-sided) }\end{array}$ & $\begin{array}{c}\text { Exact Sig. } \\
\text { (1-sided) }\end{array}$ & $\begin{array}{c}\text { Point } \\
\text { Probability }\end{array}$ \\
\hline Pearson Chi-Square & $11.000^{\mathrm{a}}$ & 1 & .001 & .003 & .003 & \\
\hline Continuity Correction ${ }^{\mathrm{b}}$ & 7.103 & 1 & .008 & & & \\
\hline Likelihood Ratio & 14.421 & 1 & .000 & .003 & .003 & \\
\hline Fisher's Exact Test & & & & .003 & .003 & \\
\hline $\begin{array}{l}\text { Linear-by-Linear } \\
\text { Association }\end{array}$ & $10.000^{\mathrm{c}}$ & 1 & .002 & .003 & .003 & .003 \\
\hline $\mathrm{N}$ of Valid Cases & 11 & & & & & \\
\hline
\end{tabular}

a. 4 cells $(100.0 \%)$ have expected count less than 5 . The minimum expected count is 1.45 .

b. Computed only for a $2 \times 2$ table

c. The standardized statistic is 3.162 .

Table 7 shows that the value of Pearson Chi-Square is 11.00, degree of freedom is 1, and p-value under Exact. Sig is 0.003 . The value of Chi-Square corresponding to $\mathrm{df}=1$ at $5 \%$ level of confidence is 3.84 .

From the above, Chi-Square value $=11.00$ is greater than Table Chi-Square value $=3.84$, this indicates that the first variable fits the analysis of the other. The p-value is 0.001 less than $5 \%$ which indicates that the relation between the two variables is statistically significant.

The exact $p$ value based on Pearson's statistic is 0.003 , compared to 0.001 for the asymptotic value. Using the exact $\mathrm{p}$ value, the null hypothesis that the two variables are independent would be rejected at the 0.05 significance level, and one would conclude that there is evidence that "The BOD approves and supervises Bank's Strat Obj." and "The BOD performs an effective and independent surveillance" are related. "The exact calculation always produces a reliable result, regardless of the size, distribution, sparseness, or balance of 
the data" (Mehta and Patel, 2012, p. 1). Furthermore, Table 7 shows that the probability of Fisher's Exact Test is .003 less than 5\%, then the null hypothesis that the two variables are independent is rejected, which indicates that the relation between the two variables is statistically significant.

Crosstab 2: "The BOD approves and supervises Bank's Strat Obj. * The BOD has free access to do corrective action"

Table 8. Chi-Square Test for Crosstab 2

\begin{tabular}{|c|c|c|c|c|c|c|}
\hline & Value & df & $\begin{array}{c}\text { Asymptotic } \\
\text { Significance } \\
\text { (2-sided) }\end{array}$ & $\begin{array}{c}\text { Exact Sig. } \\
\text { (2-sided) }\end{array}$ & $\begin{array}{c}\text { Exact Sig. } \\
\text { (1-sided) }\end{array}$ & $\begin{array}{c}\text { Point } \\
\text { Probability }\end{array}$ \\
\hline Pearson Chi-Square & $4.055^{a}$ & 1 & .044 & .088 & .088 & \\
\hline Continuity Correction $^{\mathrm{b}}$ & 1.856 & 1 & .173 & & & \\
\hline Likelihood Ratio & 4.180 & 1 & .041 & .194 & .088 & \\
\hline Fisher's Exact Test & & & & .088 & .088 & \\
\hline Linear-by-Linear Association & $3.686^{\mathrm{c}}$ & 1 & .055 & .088 & .088 & .085 \\
\hline $\mathrm{N}$ of Valid Cases & 11 & & & & & \\
\hline
\end{tabular}

a. 4 cells $(100.0 \%)$ have expected count less than 5 . The minimum expected count is 1.45 .

b. Computed only for a $2 \times 2$ table

c. The standardized statistic is 1.920 .

Table 8 shows that the value of Pearson Chi-Square is 4.055, degree of freedom is 1, and p-value under Asymp. Sig is 0.044 .

The value of Chi-Square corresponding to $\mathrm{df}=1$ at $5 \%$ level of confidence is 3.84 .

From the above, Chi-Square value $=4.055$ is greater than Table Chi-Square value $=3.84$, this indicates that the first variable fits the analysis of the other. The p-value is 0.044 less than $5 \%$ which indicates that the relation between the two variables is statistically significant.

However, with 4 cells (100.0\%) having expected count less than 5, and the minimum expected count is 1.45 , an exact test is needed. The exact $\mathrm{p}$ value based on Pearson's statistic is 0.088 , compared to 0.044 for the asymptotic value. Using the exact $p$ value, the null hypothesis would not be rejected at the 0.05 significance level, and one would conclude that there is evidence that the two variables "The BOD approves and supervises Bank's Strat Obj." and "The BOD has free access to do corrective action" " are not related. This is the opposite of the conclusion that would have been reached with the asymptotic approach. This demonstrates that when the assumptions of the asymptotic method cannot be met, the results can be unreliable. The exact calculation always produces a reliable result, regardless of the size, distribution, sparseness, or balance of the data. Moreover, to support the above, the Fisher Exact Test is performed. Table 8 shows that value of the probability of Fisher's Exact Test is .088 greater than 5\%, then the null hypothesis that the two variables are independent is not rejected, which indicates that the two variables are unrelated and the relation is not statistically significant.

Table 9. Exact Tests Options: [Null hypothesis that the two variables are independent, $\alpha=5 \%$ ]; No Rejection cases

\begin{tabular}{lll}
\hline Crosstab & $\begin{array}{l}\text { Fisher } \\
\text { Sig. (2-sided) }\end{array}$ & Exact \\
\hline $\begin{array}{l}\text { Crosstab 3: "The BOD approves and supervises Bank's Strat Obj. * } \\
\text { Preserving shareholders and depositors' interests" }\end{array}$ & $.288>.05$ & Not Rejected \\
\hline $\begin{array}{l}\text { Crosstab 7: "The BOD approves and supervises Bank's Strat Obj. * The BOD } \\
\text { set clear limits of responsibility and accountability to all” }\end{array}$ & $.727>.05$ & Not Rejected \\
\hline $\begin{array}{l}\text { Crosstab 8: "The BOD approves and supervises Bank's Strat Obj. * } \\
\text { Establishing a Management structure to promote accountability \& }\end{array}$ & $.458>.05$ & Not Rejected \\
\hline
\end{tabular}




\begin{tabular}{|c|c|c|}
\hline \multicolumn{3}{|l|}{ Responsibility" } \\
\hline $\begin{array}{l}\text { Crosstab 9: "The BOD approves and supervises Bank's Strat Obj. * The BOD } \\
\text { conducts periodic evaluations" }\end{array}$ & $1.000>.05$ & Not Rejected \\
\hline $\begin{array}{l}\text { Crosstab 10: "The BOD approves and supervises Bank's Strat Obj * Applying } \\
\text { good governance" }\end{array}$ & $.682>.05$ & Not Rejected \\
\hline $\begin{array}{l}\text { Crosstab 11: "The BOD approves and supervises Bank's Strat Obj * The BOD } \\
\text { applies good governance for the group as a whole" }\end{array}$ & $.545>.05$ & Not Rejected \\
\hline $\begin{array}{l}\text { Crosstab 12: "The BOD approves and supervises Bank's Strat Obj * The BOD } \\
\text { deals with risk as most important priority" }\end{array}$ & $.829>.05$ & Not Rejected \\
\hline $\begin{array}{l}\text { Crosstab 13: "The BOD approves and supervises Bank's Strat Obj * The bank } \\
\text { respects BDL decisions and risk management" }\end{array}$ & $1.000>.05$ & Not Rejected \\
\hline $\begin{array}{l}\text { Crosstab 14: "The BOD approves and supervises Bank's Strat Obj * The BOD } \\
\text { ensures wages and reward policies fit culture \& bank's strategic plans" }\end{array}$ & $1.000>.05$ & Not Rejected \\
\hline $\begin{array}{l}\text { Crosstab 15: "The BOD approves and supervises Bank's Strat Obj * The BOD } \\
\text { manages the bank with effectiveness due to legal risks" }\end{array}$ & $.685>.05$ & Not Rejected \\
\hline $\begin{array}{l}\text { Crosstab 17: "The BOD approves and supervises Bank's Strat Obj * The BOD } \\
\text { discloses info about established committees" }\end{array}$ & $.194>.05$ & Not Rejected \\
\hline $\begin{array}{l}\text { Crosstab 21: "The BOD is constantly subject to courses and workshops to } \\
\text { enhance its efficiency, especially regarding the corporate governance of banks } \\
\text { * The Council shall conduct periodic evaluation to all members and to each } \\
\text { one of them separately, in order to achieve improvement and doing necessary } \\
\text { adjustments" }\end{array}$ & $.714>.05$ & Not Rejected \\
\hline $\begin{array}{l}\text { Crosstab 28: "Disclosure includes information related to substantial risks the } \\
\text { bank is exposed to * The administration is committed to disclose accounting } \\
\text { policies concerning bank risks" }\end{array}$ & $.219>.05$ & Not Rejected \\
\hline
\end{tabular}

\section{Chi-Square Test for Crosstab}

Table 10. Exact Tests Options: [Null hypothesis that the two variables are independent, $\alpha=10 \%$ ]; Rejection cases

\begin{tabular}{|c|c|c|}
\hline \multirow[t]{2}{*}{ Crosstab } & Fisher Exact & Decision \\
\hline & \multicolumn{2}{|l|}{ Sig. (2-sided) } \\
\hline $\begin{array}{l}\text { Crosstab 2: "The BOD approves and supervises Bank's Strat Obj. * The BOD has } \\
\text { free access to do corrective action" }\end{array}$ & $.088<.10$ & Rejected \\
\hline $\begin{array}{l}\text { Crosstab 6: "The BOD approves and supervises Bank's Strat Obj. * The BOD } \\
\text { duties \& Responsibilities are specified with Rules \& Regulations" }\end{array}$ & $.088<.10$ & Rejected \\
\hline $\begin{array}{l}\text { Crosstab 20: "Members of the board of directors are chosen and assigned on the } \\
\text { basis of their administrative experience and academic qualifications * Board } \\
\text { members have various academic qualifications that allow objective expression of } \\
\text { opinions" }\end{array}$ & $.088<.10$ & Rejected \\
\hline $\begin{array}{l}\text { Crosstab 24: "The risk management committee has complete freedom to take } \\
\text { information at any time it needs } * \text { The members of the risk management } \\
\text { committee possess required qualifications given the importance of this } \\
\text { administration" }\end{array}$ & $.061<.10$ & Rejected \\
\hline $\begin{array}{l}\text { Crosstab 27: "The senior management has surveillance on bank activities in case } \\
\text { of illegal activities which might put the bank's reputation at risk * A clear } \\
\text { structure that complies with the bank's policy and strategy is adopted" }\end{array}$ & $.055<.10$ & Rejected \\
\hline
\end{tabular}

Crosstabs 30: "The BOD approves and supervises Bank's Strategic Objectives * Three statements" 
Table 11. Fisher's Exact Test Crosstabs 30

\begin{tabular}{|c|c|}
\hline & $\begin{array}{l}\text { The BOD approves and supervises } \\
\text { Bank's Strategic Objectives }\end{array}$ \\
\hline \multirow[t]{2}{*}{ President of BOD takes appropriate decisions after discussions } & Value $=6.311$ \\
\hline & Exact Sig. $(2$-sided $)=.024$ \\
\hline \multirow[t]{2}{*}{ The BOD ensures Policies exist to reduce conflict of interest } & Value $=8.278$ \\
\hline & Exact Sig. $(2$-sided $)=.006$ \\
\hline \multirow{2}{*}{$\begin{array}{l}\text { Senior Management monitors bank's performance by monitoring BOD } \\
\text { performance }\end{array}$} & Value $=7.382$ \\
\hline & Exact Sig. $(2$-sided $)=.024$ \\
\hline \multirow{2}{*}{$\begin{array}{l}\text { Incentives for Senior Managers and Executive Managers meet bank's } \\
\text { long-term goals }\end{array}$} & Value $=7.868$ \\
\hline & Exact Sig. $(2$-sided $)=.017$ \\
\hline
\end{tabular}

Table 11 shows that the probability of Fisher's Exact Test is .024, .006, .024 and .017 less than 5\%, for the cross tabulations "The BOD approves and supervises Bank's Strategic Objectives" and "President of BOD takes appropriate decisions after discussions', "The BOD ensures Policies exist to reduce conflict of interest", "Senior Management monitors bank's performance by monitoring BOD performance", "Incentives for Senior Managers and Executive Managers meet bank's long-term goals", respectively, then the null hypothesis that every pair of variables are independent is rejected, which indicates that the relation between each of the two variables within the three pairs are statistically significant.

Table 11 provides good evidence that banks are abiding by their strategic objectives set by top management whereby appropriate decision making is ongoing, conflict of interest is under control, appropriate incentives are provided to top management and banks' performance is monitored. As a matter of fact strategic decisions in Lebanese banks abide by the Lebanese Central Bank standards and the international standards set by Basel agreements.

Crosstabs 31: "The BOD approves and supervises Bank's Strategic Objectives * Eleven statements"

Table 12. Fisher's Exact Test Crosstabs 31

\begin{tabular}{|c|c|}
\hline & $\begin{array}{l}\text { The BOD approves and supervises } \\
\text { Bank's Strategic Objectives }\end{array}$ \\
\hline $\begin{array}{l}\text { The Risk Management Committee has complete freedom to take } \\
\text { information as needed }\end{array}$ & $\begin{array}{l}\text { Value }=6.316 \\
\text { Exact Sig. }(2 \text {-sided })=.024\end{array}$ \\
\hline The Risk Management Committee possesses required qualifications & $\begin{array}{l}\text { Value }=9.417 \\
\text { Exact Sig. }(2 \text {-sided })=.015\end{array}$ \\
\hline The Director of Risk Management Committee holds one position & $\begin{array}{l}\text { Value }=8.433 \\
\text { Exact Sig. }(2 \text {-sided })=.008\end{array}$ \\
\hline Bank has an Internal Audit unit & $\begin{array}{l}\text { Value }=8.392 \\
\text { Exact Sig. }(2 \text {-sided })=.024\end{array}$ \\
\hline Bank Internal Audit is independent & $\begin{array}{l}\text { Value }=8.684 \\
\text { Exact Sig. }(2 \text {-sided })=.008\end{array}$ \\
\hline Bank Internal Audit Process is ran on regular basis & $\begin{array}{l}\text { Value }=7.719 \\
\text { Exact Sig. }(2 \text {-sided })=.033\end{array}$ \\
\hline Bank Internal Audit is regulated with laws and policies & $\begin{array}{l}\text { Value }=9.417 \\
\text { Exact Sig. }(2 \text {-sided })=.015\end{array}$ \\
\hline $\begin{array}{l}\text { Internal Auditors are qualified (efficient, experienced and quality } \\
\text { work) }\end{array}$ & $\begin{array}{l}\text { Value }=9.417 \\
\text { Exact Sig. }(2 \text {-sided })=.015\end{array}$ \\
\hline Internal Auditors pledge not to exploit info for personal benefit & $\begin{array}{l}\text { Value }=9.652 \\
\text { Exact Sig. }(2 \text {-sided })=.043\end{array}$ \\
\hline The administration discloses accounting policies about bank risks & $\begin{array}{l}\text { Value }=5.961 \\
\text { Exact Sig. }(2 \text {-sided })=.048\end{array}$ \\
\hline $\begin{array}{l}\text { The bank considers the External Auditor notes about financial } \\
\text { statements }\end{array}$ & $\begin{array}{l}\text { Value }=10.069 \\
\text { Exact Sig. }(2 \text {-sided })=.003\end{array}$ \\
\hline
\end{tabular}


Table 12 shows that the probability of Fisher's Exact Tests are all less than 5\%, for the eleven cross tabulations, then the null hypothesis that every pair of the variables stated above are independent is rejected, which indicates that the relation between the two variables forming each of the eleven pairs is statistically significant. Actually, Table 12 provides good evidence that banks are abiding by their strategic objectives set by top management whereby appropriate controls are set internally and externally as required by the Lebanese Central Bank standards and the international standards set by Basel agreements.

4.14 Reliability Test

Table 13. Reliability Statistics

\begin{tabular}{ccc}
\hline Cronbach's Alpha & Cronbach's Alpha Based on Standardized Items & N of Items \\
\hline .971 & .976 & 60 \\
\hline
\end{tabular}

An assessment of the internal consistency of each survey set of items was performed, essentially assessing whether all the items belonging to one set were measuring the same thing by using Cronbach's alpha technique where the reliability increases when the alpha value approaches 1 . According to Burns \& Burns (2008), an alpha value of 0.8 or above is regarded as highly acceptable for assuming homogeneity of items, while an alpha value that is greater than 0.7 is considered appropriate even though this value could be as low as 0.6 for exploratory research (Hejase \& Hejase, 2013). Thus, the resulting Cronbach's alphas after the suggested eliminations was 0.976 (see Table 13) which is highly acceptable as measures of internal reliability for the survey scale in the Likert section. Chehimi et al. (2019, p. 1915) contends that the aforementioned indicates an excellent strength of association and supports the suitability and selection of the questions for the questionnaire purpose.

\section{Conclusion and Recommendations}

\subsection{Conclusion}

Corporate Governance is considered one of the most interesting topics which gained popularity by all economists, locally, regionally, and internationally. The growing interest in this subject is due to the financial crisis which resulted from mismanagement and the spread of financial and administrative corruption. The outcomes of the aforementioned actions affected the largest economic systems in the world.

Based and due to the above outcomes, many of the countries adopted the concept of Corporate Governance and made special efforts to the application of its principles in the business sector, in general, and the banking sector, in particular. The banking sector was targeted because of its direct influence on the national economic systems, that is, it is relied upon in the financing of all economic activities. Consequently, any crisis that threatens the financial stability, leads to the occurrence of large imbalances in the macro-economic system. On the other side, the evolution of the banking sector's performance will affect positively the high performance of the economic system which in turn will lead to national prosperity and economic development.

This study, titled: "Corporate Governance in the banking sector," provided a detailed review of corporate governance in the financial institutions and banks, as well as touched upon the most important aspects of the Basel Committee and its foundation. Moreover, this study covered the most important decisions and their role in promoting the adoption of the principles of corporate governance, in particular taking Lebanon as the case study. The study based its analysis on two approaches; the theoretical and the analytical based on quantitative analysis.

\subsection{The Overall Results of the Study}

The success of corporate governance in banks requires the application of its rules properly. This depends on the control of the Central Bank and the Bank's management.

The application of governance in banks has become imperative so that they can compete with the rest of the banks and maintain its continuity.

The principle of transparency and disclosure of the financial position of the banks help to strengthen the confidence of their clients and, thus, improve their performance.

Adherence to the principle of transparency contributes to the reduction of banking crises and improves the reputation of the banks.

Governance has become a fundamental criterion to which clients base their decisions to deal with the banking sector. Governance guarantees that the banks' decisions protect its clients' rights, and 
at the same time acts as a critical success factor to attract and gain new customers.

\subsection{Results of the Research's Hypotheses}

This research has shown that the Lebanese respondents representing eleven banks out of 59 banks listed in the Central Bank, are highly aware of the principles of Corporate Governance applied to the banking sector and at the same time have shown good understanding of the requirements set by the Central Bank. Moreover, this research tested four hypotheses, namely:

\section{Hypothesis One:}

$\mathrm{Ha}_{0}$ : The concept of governance is not important in selected Lebanese banks

$\mathrm{Ha}_{1}$ : The concept of governance is important in selected Lebanese banks

\section{Hypothesis Two:}

$\mathrm{Hb}_{0}$ : There is no relation between applying governance and Basel standards in Lebanese banks

$\mathrm{Hb}_{1}$ : There is a relation between applying governance and Basel standards in Lebanese banks

\section{Hypothesis Three:}

$\mathrm{Hc}_{0}$ : Lebanese banks do not apply governance effectively

$\mathrm{Hc}_{1}$ : Lebanese banks do apply governance effectively

\section{Hypothesis Four:}

$\mathrm{Hd}_{0}$ : The laws regulating corporate governance in Lebanon do not match recommended governance standards

$\mathrm{Hd}_{1}$ : The laws regulating corporate governance in Lebanon do match recommended governance standards

\section{Hypothesis One:}

Concerning the first hypothesis, the importance of governance in banking is shown through an applied study of the senior management's surveillance of the bank's activities in case there are illegal activities which might affect the reputation of the bank. A clear structure which suits the policies and strategies of the bank should be adopted. In addition, the senior management should be committed to disclosing accounting policies regarding the bank's potential risks.

Findings show the respondents inputs on three statements related to governance application within the banking group. $100 \%$ of the respondents agree that the BOD applies good governance across the group; while $90.9 \%$ agree that there exists a suitable structure for governance to assure effective supervision; also $100 \%$ of the respondents agree that their BODs use suitable surveillance means for compliance and good governance within the group. Further analysis for the first hypothesis shows that the alternative hypothesis is accepted and the Null hypothesis is rejected. The relationships supporting the importance are both statistically significant.

\section{Alternative Hypothesis: Ha $\mathrm{H}_{1}$ : The concept of governance is important in selected Lebanese banks Relationship One:}

Crosstab 22: "Applying good governance * Suitable structure for governance to assure effective supervision"

Exact Chi-Square analysis as well as Fisher's Exact Test indicate that the first variable does fit the analysis of the other, and the relation between the two variables is statistically significant. Therefore, the Alternative Hypothesis: $H a_{1}$ : The concept of governance is important in selected Lebanese banks is accepted.

\section{Relationship Two:}

Crosstab 23: "The BOD behavior reflects productivity of the bank * The BOD applies good governance for the group as a whole"

Exact Chi-Square analysis as well as Fisher's Exact Test indicate that the first variable does fit the analysis of the other, and the relation between the two variables is statistically significant. Therefore, the Alternative Hypothesis: $\mathrm{Ha}_{1}$ : The concept of governance is important in selected Lebanese banks is accepted.

The two relations discussed above support the importance of governance in banking.

\section{Hypothesis Two:}

The second hypothesis asserts that there is a relationship between the application of corporate governance and Basel standards in Lebanon because the application of these standards resulted in positive effects such as:

- Strengthening customers' confidence in Lebanese banks 
- Succeeding in escaping and avoiding financial banking crises

- Limiting the spread of financial and administrative corruption

- Disclosure and transparency practices

- Improving banking performance

The Board of Directors of Lebanese banks have the responsibility to comply with Basel standards, a fact that is also encouraged by the Central Bank of Lebanon. Applying these standards is governed by the banks' strategy and the mechanisms adopted to implement the strategy. Such facts are supported by the results of this research. According to Table 2, respondents representing the sample of Lebanese banks show a strong understanding of the responsibility of members of the Board of Directors (63.6\% strongly agree and 36.4\% agree), whereby, they stressed the strategic objectives, free access to perform corrective actions, and practicing effective and independent surveillance. Moreover, they agree on the supervision function on top management (54.5\% strongly agree, $45.5 \%$ agree) and the commitment to preserving shareholders and depositors' interests $(54.5 \%$ strongly agree and $27.3 \%$ agree while $9.10 \%$ were either neutral or disagree).

Moreover, section 4.10 and Table 5 support the fact that representatives of the Lebanese banks enforce disclosure and transparency practices in the banks. Results show that $36.4 \%$ of the respondents strongly agree and $54.5 \%$ agree that the banks disclose all information about activities and operations, whereby according to $72.8 \%$ of the respondents strongly agree and agree the disclosure includes information related to substantial risks, while $18.2 \%$ are neutral. Moreover, $54.5 \%$ of the respondents strongly agree and $36.4 \%$ agree that their BODs disclose information about established committees in their banks. Furthermore, 36.4\% of the respondents strongly agree and $45.5 \%$ agree that the administration discloses accounting policies about bank risks. Also, $54.5 \%$ of the respondents strongly agree and $36.4 \%$ agree while $9.1 \%$ are neutral that the banks take into consideration the External Auditors' notes about the banks' financial statements. Finally, $63.6 \%$ of the respondents strongly agree and $27.3 \%$ agree while $9.1 \%$ are neutral that that centrality is adopted when approving and supervising the establishment of affiliated new institutions, while $9.1 \%$ are neutral that disclosure must be clear, understandable, and accurate.

Further analysis for the second hypothesis shows that the alternative hypothesis is accepted and the Null hypothesis is rejected. The relationships supporting the importance are statistically significant.

\section{Alternative Hypothesis $\mathrm{Hb}_{1}$ : There is a relation between applying governance and Basel standards in Lebanese banks}

\section{Relationship One:}

Crosstab 1: "The BOD approves and supervises Bank's Strat Obj. * The BOD performs an effective and independent surveillance"

Exact Chi-Square analysis as well as Fisher's Exact Test indicate that the first variable does fit the analysis of the other, and the relation between the two variables is statistically significant.

\section{Relationship Two:}

Crosstab 16: "The BOD approves and supervises Bank's Strat Obj * Bank has clear structure that complies with policy \& strategy adopted"

Exact Chi-Square analysis and Fisher's Exact Test indicate that the first variable does fit the analysis of the other, and the relation between the two variables is statistically significant.

\section{Relationship Three:}

Crosstab 17: "The BOD approves and supervises Bank's Strat Obj * The BOD discloses info about established committees"

Exact Chi-Square analysis as well as Fisher's Exact Test indicate that the first variable does fit the analysis of the other, and the relation between the two variables is statistically significant.

\section{Relationship Four:}

Crosstabs 30: "The BOD approves and supervises Bank's Strategic Objectives * Three statements" (see Table 17).

Fisher's Exact Tests in the four statements (1) President of BOD takes appropriate decisions after discussions; (2) The BOD ensures Policies exist to reduce conflict of interest; (3) Senior Management monitors bank's performance by monitoring BOD performance; and (4) Incentives for Senior Managers and Executive Managers 
meet bank's long-term goals indicate that the first variable does fit the analysis of the other four, and the relation between the set of variables is statistically significant.

The four relations discussed above support required Basel requirements including: existence of a responsible Board of Directors whose roles are defined, existence of bank strategies, existence of rules and regulations, actions related to monitoring and performance follow up, committees formations, and transparency and public disclosure.

Since Fisher's Exact Test is statistically significant, the alternative hypothesis $\mathrm{Hb}_{1}$ is not rejected.

\section{Hypothesis Three:}

Regarding the third hypothesis, it is observed that descriptive statistics show that respondents agree about the three statements depicting the BODs' practices related to governance. However, when reviewing the results of cross-tabulations related to the same, one may conclude that the concerned Lebanese banks also show high effectiveness in applying governance.

Governance is manifested in the application of the standards by a well selected body (BODs) and focus on internal control in banks and how risks are managed.

$\mathrm{Hc}_{0}$ : Lebanese banks do not apply governance effectively

$\mathrm{Hc}_{1}$ : Lebanese banks do apply governance effectively

First of all, the discussion performed in the proof for hypothesis one, shows that respondents' inputs on three statements are related to the importance of governance application within the banking group.

Second, Table 8 shows that the respondents' inputs on twelve statements related to internal and external auditors and the role of internal auditing are positive reflecting strong agreement (above 80\%), however, not enough to stress effectiveness. Therefore, to test effectiveness, eight crosstabs are used.

\section{Relationship One:}

Crosstab 18: "The BOD performs an effective and independent surveillance of the bank * The BOD supervises the performance of senior management"

Exact Chi-Square analysis and Fisher's Exact Test indicate that the first variable does fit the analysis of the other, and the relation between the two variables is statistically significant.

\section{Relationship Two:}

Crosstab 5: "The BOD approves and supervises Bank's Strat Obj. * The BOD form committees: Audit \& Risk"

Exact Chi-Square analysis and Fisher's Exact Test indicate that the first variable does fit the analysis of the other, and the relation between the two variables is statistically significant.

\section{Relationship Three:}

Crosstab 22: "Applying good governance * Suitable structure for governance to assure effective supervision"

Exact Chi-Square analysis as well as Fisher's Exact Test indicate that the first variable does fit the analysis of the other, and the relation between the two variables is statistically significant.

\section{Relationship Four:}

Crosstab 23: "The BOD behavior reflects productivity of the bank * The BOD applies good governance for the group as a whole"

Exact Chi-Square analysis as well as Fisher's Exact Test indicate that the first variable does fit the analysis of the other, and the relation between the two variables is statistically significant.

\section{Relationship Five:}

Crosstab 16: "The BOD approves and supervises Bank's Strat Obj* Bank has clear structure that complies with policy \& strategy adopted"

Exact Chi-Square analysis as well as Fisher's Exact Test indicate that the first variable does fit the analysis of the other, and the relation between the two variables is statistically significant.

\section{Relationship Six:}

Crosstab 25: "Internal Auditors are qualified (efficient, experienced and quality work) * Internal Auditors pledge to disclose all financial facts reached" 
Exact Chi-Square analysis as well as Fisher's Exact Test indicate that the first variable does fit the analysis of the other, and the relation between the two variables is statistically significant.

\section{Relationship Seven:}

Crosstab 29: "Disclosure includes information related to substantial risks the bank is exposed to * Bank discloses all info about activities \& operations"

Exact Chi-Square analysis as well as Fisher's Exact Test indicate that the first variable does fit the analysis of the other, and the relation between the two variables is statistically significant.

\section{Relationship Eight:}

Crosstabs 31: "The BOD approves and supervises Bank's Strategic Objectives * Three statements" (see Table 12)

Fisher's Exact Tests in the three statements: (1) The Risk Management Committee has complete freedom to take information as needed; (2) The Risk Management Committee possesses required qualifications; and (3) The Director of Risk Management Committee holds one position, indicate that the first variable does fit the analysis of the other three, and the relation between the set of variables is statistically significant.

Moreover, the other eight crosstabs statements (Table 12) tested with either Exact Chi-square analysis and/or Fisher's Exact Test demonstrate that when it comes to operational practices applying governance effectively versus the Banks' objectives, all of the crosstabs were statistically significant. Therefore, leading to demonstrate that for hypothesis three, we accept the Alternative hypothesis.

\section{$\mathrm{Hc}_{1}$ : Lebanese banks do apply governance effectively}

\section{Hypothesis Four:}

The fourth hypothesis (the laws regulating corporate governance in Lebanon do match recommended governance standards) could be applied through laws and decrees issued by the Central Bank of Lebanon (BDL, 2011a, April 21) as:

- It plays key roles in the Lebanese economy where banks continue to dominate the financial system of the country and are major providers of credit to individuals and businesses.

- It controls entry into the banking industry, defines the scope of banking activities, and sets prudential regulations and codes of practice for banks.

- The Lebanese banks are ready to implement the principles issued by Basel III regarding their capitals by the end of 2019.

- The banks' supervisory authority has recommended all Lebanese banks to take and apply the international capital standards starting from Basel I, II, and III. Supervisory authority recommended implementing these standards in the shortest period of time; for instance, capital funds will be $12 \%$ by the end of 2019 , not to forget that the solvency ratio was $8 \%$.

$\mathrm{Hd}_{0}$ : The laws regulating corporate governance in Lebanon do not match recommended governance standards

$\mathrm{Hd}_{1}$ : The laws regulating corporate governance in Lebanon do match recommended governance standards

Banque du Liban (BDL, Central Bank of Lebanon) has made it clear through circular No. 255 that all Lebanese banks must apply the norms of rational banking administration, depicted in Exhibit 2, and which enforce Basel requirements (BDL, 2011a, April 21). The Central Bank has been very active and in direct contact with all Lebanese banks offering advice and mentoring in the application of governance principles. All through the aforementioned process, Lebanese banks report directly the completion of all governance requirements. Next, to support hypothesis four testing descriptive statistics and crosstabs are used.

One important initial step towards the application of governance is to set clear criteria to define qualifications, independence, and formation of the members of the banks' Board of Directors. Results from section 4.2, representing the sample of Lebanese banks, show that the respondent managers believe that their Board of Directors are formed from reputable persons who show integrity (81.2\% strongly agree and $18.8 \%$ agree) and they also confirm that the BOD duties and responsibilities are specified with Rules \& Regulations (63.6\% strongly agree and $36.4 \%$ agree). Moreover, respondents agree $(54.5 \%$ strongly agree and $45.5 \%$ agree) that there are audit and risk management committees and the BOD includes two independent members to guarantee impartiality. Furthermore, and with lower average agreement (36.4\% strongly agree and $63.6 \%$ agree), respondents believe that members of the BOD are selected based on experience, qualifications, and academic 
preparation. Respondents showed lowest degree of agreement and higher neutrality when they were asked if BOD members are trained with courses and workshops to boost efficiency and governance.

However, to test hypothesis four, seven crosstab analyses are performed.

\section{Relationship One:}

Crosstab 5: "The BOD approves and supervises Bank's Strat Obj. * The BOD form committees: Audit \& Risk"

Exact Chi-Square analysis and Fisher's Exact Test indicate that the first variable does fit the analysis of the other, and the relation between the two variables is statistically significant.

\section{Relationship Two:}

Crosstab 16: "The BOD approves and supervises Bank's Strat Obj * Bank has clear structure that complies with policy \& strategy adopted"

Exact Chi-Square analysis and Fisher's Exact Test indicate that the first variable does fit the analysis of the other, and the relation between the two variables is statistically significant.

\section{Relationship Three:}

Crosstab 18: "The BOD performs an effective and independent surveillance of the bank * The BOD supervises the performance of senior management"

Exact Chi-Square analysis and Fisher's Exact Test indicate that the first variable does fit the analysis of the other, and the relation between the two variables is statistically significant.

\section{Relationship Four:}

Crosstab 19: "The BOD has free access to information to do corrective action" * President of BOD takes appropriate decisions after holding important discussions for the benefit of the bank"

Exact Chi-Square analysis and Fisher's Exact Test indicate that the first variable does fit the analysis of the other, and the relation between the two variables is statistically significant.

\section{Relationship Five:}

Crosstab 25: "Internal Auditors are qualified (efficient, experienced and quality work) * Internal Auditors pledge to disclose all financial facts reached"

Exact Chi-Square analysis as well as Fisher's Exact Test indicate that the first variable does fit the analysis of the other, and the relation between the two variables is statistically significant.

\section{Relationship Six:}

Crosstab 28: "Disclosure includes information related to substantial risks the bank is exposed to * The administration is committed to disclose accounting policies concerning bank risks"

Exact Chi-Square analysis and Fisher's Exact Test indicate that the first variable does fit the analysis of the other, and the relation between the two variables is statistically significant.

\section{Relationship Seven:}

Crosstabs 30: "The BOD approves and supervises Bank's Strategic Objectives * Three statements" (see Table 11)

Fisher's Exact Tests in the four statements: (1) President of BOD takes appropriate decisions after discussions; (2) The BOD ensures Policies exist to reduce conflict of interest; (3) Senior Management monitors bank's performance by monitoring BOD performance; and (4) Incentives for Senior Managers and Executive Managers meet bank's long-term goals, indicate that the first variable does fit the analysis of the other four, and the relation between the set of variables is statistically significant. The aforementioned four relations discussed, support required Basel requirements including: existence of a responsible Board of Directors whose roles are defined, existence of bank strategies, existence of rules and regulations, actions related to monitoring and performance follow up, committees formations, and transparency and public disclosure.

\section{Relationship Eight:}

Crosstabs 31: "The BOD approves and supervises Bank's Strategic Objectives * Three statements" (see Table 12)

Fisher's Exact Tests in the three statements: (1) The Risk Management Committee has complete freedom to take information as needed; (2) The Risk Management Committee possesses required qualifications; and (3) The 
Director of Risk Management Committee holds one position, indicate that the first variable does fit the analysis of the other three, and the relation between the set of variables is statistically significant.

Moreover, the other eight crosstabs statements (Table 12) tested with either Exact Chi-square analysis and/or Fisher's Exact Test demonstrate that when it comes to operational practices applying governance effectively versus the Banks' objectives, all of the crosstabs were statistically significant. Actually, the null hypothesis that every pair of the variables stated are independent is rejected, which indicates that the relation between the two variables forming each of the eleven pairs is statistically significant.

Eight crosstabs tested with either Exact Chi-square analysis and/or Fisher's Exact Test demonstrate that when it comes to matching the laws regulating corporate governance in Lebanon, as monitored by the Central Bank, do match recommended governance standards by international bodies. Therefore, stressing that for hypothesis four, we accept the Alternative hypothesis.

\section{$H d_{1}$ : The laws regulating corporate governance in Lebanon do match recommended governance standards}

\subsection{Recommendations}

This paper shows that one very important aspect has to be considered carefully namely, the operationalization of all governance principles and standards within the Lebanese banks. Reaching appropriate effectiveness in the banks' objectives, necessitates more attention from top management in encouraging and rewarding the appropriate implementation of the standards. First, because effectiveness of banks is monitored by the Central Bank and second because of the continuity and sustainability of the banks. The global requirements are becoming more stringent, and therefore the Lebanese banks have to raise all employees' awareness about the concept of governance through training in-house and attending conferences and seminars about the topic.

One sound practice is that all Lebanese banks are abiding by all requirements for governance in such a way that Lebanese banks have established an internal code for corporate governance stating all needed requirements. For example Credit Bank (2015) contends that, "the Board of the Bank has formally resolved to adopt a Corporate Governance Code (the Code) which conforms to the requirements and recommendations of the Lebanese Central Bank and Banking Control Commission in particular the principal circular $n^{\circ} 106$ dated 26/07/2006, as well as international best practice" (Para 1).

\subsection{Limitations of the Research}

This research has its limitations as well:

1. It was subject to a tight time constraint preventing the authors from expanding her investigation in the Lebanese territory.

2. Very low overall response $(11 / 59=18.64 \%$, Alpha Group $18.75 \%$; $20 \%$ Beta Group; $14.3 \%$ Gamma Group; and 19\% Delta Group):

A. The researchers faced high resistance by many Lebanese banks to participate and therefore preventing interviews with more senior managers.

B. The researchers had hard time following up with the respondent managers to complete the interview questionnaires due to their extensive commitments.

3. It should have included one-to-one interview sessions with individuals who are very much aware about Lebanese corporate Governance practices and who are regarded as experts in this, which would make the researchers find out about the obstacles of incorporating corporate governance practices in daily encounters and decision making even at the lower ranks.

4. Results are exploratory in nature, therefore may not be generalized to include all Lebanese banks.

\subsection{Future Research}

Board of Directors' decisions are important application of corporate governance, with individual and group level decisions made daily Levrau \&Van Den Berghe, 2007; Namoga, 2010). Banker-client interaction is an area that involves both financial security and thoughts and emotions of satisfaction, and this is an important area of marketing that may benefit from the transparent relationship assured by corporate governance with clients' behavior. In particular, addressing the risk factors in dealing with banking practices. Although not formally tested in this research, the effectiveness in successful clients' satisfaction scenarios is likely to be positively related to the choice of the bank. Furthermore, the banks' performance may also be a positive outcome of employees' use of governance principles when interacting with clients.

There is little doubt, however, that corporate governance can become a central component for numerous 
exchange relationships in all aspects of personal and professional banking experiences. Therefore, researching the role of internal auditing in effectuating corporate governance in banks becomes an important need. Finally, this research may be highly enriched if a much larger sample of Lebanese banks participate. One possible enhancing force for the research to reach its objectives is involving the Central Bank.

\section{References}

Abed Hamid, A. M. (2002-2003). In Globalization and the economics of banks (pp. 82-83). Egypt.

Abed Razak, H. (2009). Comply with the requirements of the Basel Committee as an input to establish corporate governance in the banking sector. Magazine economies of North Africa, 7, 80 .

Advantage Consulting Company. (2009). Nothing but Common Sense: Immunity of Lebanese Banks facing the Global crisis. Markets Insights Division - MID. Kuwait: Advantage Consulting Company. Retrieved March 21, 2021, from http://www.databank.com.lb/docs/Immunity\%20of\%20Lebanese\%20Banks $\% 20$ facing $\% 20$ the $\% 20 \mathrm{Global} \%$ 20crisis-MID.pdf

AdvisoryHQ. (2016). From Basel I to Basel III - Overview of the Journey (Basel 1, 2, 2.5 and 3). Retrieved March 21, 2021, from http://www.advisoryhq.com/articles/basel-i-2-2-5-3/

Aidt, T. (2009). Corruption, institutions and economic development. Oxford Review of Economic Policy, 25, 271-291. https://doi.org/10.1093/oxrep/grp012

AL Mal Wal, A. (2010). How Lebanon avoided getting affected by the poisoning drawsbacks of international crisis. AL Mal Wal Aalam, (265), 21.

Al Saidi, N. (2004). Corporate Governance in MENA countries: Improving transparency and disclosure. The second Middle East and North Africa Regional Corporate Governance Forum, Beirut, June 3-5, 2004. Baabda, Lebanon: The Lebanese Transparency Association. Retrieved March 21, 2021, from http://documents1.worldbank.org/curated/en/636881488970137694/pdf/113238-WP-Transparency-and-Dis closure.pdf

Al Sayed, F. (2016). Customer-Centricity Success Factors: Context of Lebanese Market. (MBA Research Project), Faculty of Business and Economics, American University of Science and Technology, Beirut, Lebanon.

Alem, Associates, Étude Badri, \& Salim El Meouchi. (2005, September). A Review of the Legal and Regulatory Framework Pertaining to the Corporate Governance of Banks in Lebanon. Report commissioned by Association of Banks in Lebanon (ABL) and International Finance Corporation (IFC).

American Psychological Association (APA). (2017). Ethical Principles of Psychologists and Code of Conduct. American Psychological Association (APA). Retrieved March 21, 2021, from https://www.apa.org/ethics/code/ethics-code-2017.pdf

Association of Banks in Lebanon (ABL). (2011, July 5). Conference on Corporate Governance for Banks operating in Lebanon. Retrieved March 21, 2021, from https://www.abl.org.lb/english/abl-and-banking-sector-news/abl-news/conference-on--corporate-governanc e-for-banks-operating-in-lebanon-

Association of Chartered Certified Accountants (ACCA). (2016, March 7). Corporate Governance- from the Inside Out. Retrieved March 27, 2021, from https://www.accaglobal.com/gb/en/student/exam-support-resources/professional-exams-study-resources/str ategic-business-leader/technical-articles/corporate-governance-inside-out.html

Associations of Banks in Lebanon - ABL. (2015, September 10). Lebanese Banking Sector: Main $\begin{array}{lllll}\text { Characteristics. } & \text { Retrieved } & \text { February } & \text { 2021, }\end{array}$ https://www.abl.org.lb/english/about-abl/main-characteristics

Bank for International Settlements - BIS (1999, April). Capital Requirements and Bank Behavior: The Impact of the Basle Accord. Basle Committee on Banking Supervision Working papers, No. 1, Basle, Switzerland. Retrieved October 14, 2016, from http://www.bis.org/publ/bcbs_wp1.pdf

Bank for International Settlements - BIS (2015c, October). A Brief History of the Basel Committee. Basel Committee on Banking Supervision. Retrieved March 21, 2021, from http://www.bis.org/bcbs/history.pdf

Bank for International Settlements (BIS). (2011, June). Principles for the Sound Management of Operational Risk and the Role of Supervision. Retrieved October 21, 2016, from http://www.bis.org/publ/bcbs195.pdf 
Bank for International Settlements (BIS). (2015a, January 9). Corporate governance principles for banks. Basel Committee on Banking Supervision Consultative document Guidelines. Retrieved February 22, 2021, from http://www.bis.org/publ/bcbs294.pdf

Bank for International Settlements (BIS). (2015b, July). Corporate governance principles for banks. Retrieved March 23, 2021, from http://www.bis.org/bcbs/publ/d328.htm

Banking Control Commission of Lebanon - BCCL. (2021). History and Duties. Retrieved March 21, 2021, from http://www.bccl.gov.lb/committee/history/

Banking Control Commission-Lebanon (BCCL). (2004, June 30). Fundamentals of Risk Management in Banks and Financial Institutions. Banking Supervision Commission, Circular 242. Retrieved April 5, 2021, from http://www.bccl.gov.lb/pdf_files/international_standards_pdf_files/risk_management/bccl_cir_no_242.pdf

Banque du Liban - BDL (2006a, April 1). Implementation of the Basle II Capital Adequacy Accord. Decision 9302. Basic Circular No. 104. Retrieved February 22, 2021, from https://www.banqueduliban.gov.lb/circulars/index/5/33/0/Basic-Circulars.html

Banque du Liban - BDL. (2000, December 15). Basic Decision No 7737 of December 15, 2000 relating to Internal Control and Internal Audit in Banks and Financial Institutions. Basic Circular No 77. Retrieved March 14, 2021, from http://www.bccl.gov.lb/pdf_files/international_standards_pdf_files/internal_audit/bdl_basic_cir_no_77.pdf

Banque du Liban - BDL. (2004). BDL main stream number 242. Beirut, Lebanon.

Banque du Liban - BDL. (2006b, March 9). Basic Decision No 9286 of March 9, 2006 relating to academic, technical and ethical qualifications required for performing certain functions in the banking and financial sectors. Basic Circular No 103. Beirut, Lebanon. Retrieved October 14, 2016, from www.bdl.gov.lb/circulars/download/109/en

Banque du Liban - BDL. (2007, December 14). Required information about the Management of banks and financial institutions. Decision 9793. Basic Circular No 114. Retrieved March 12, 21, from http://www.bdl.gov.lb/circulars/index/5/33/1

Banque du Liban - BDL. (2008, July 21). Assessment of Bank Capital Adequacy. Decision 9957. Basic Circular No. $119 . \quad$ Retrieved $\quad$ February 22, 2021, from https://www.banqueduliban.gov.lb/circulars/index/5/33/0/Basic-Circulars.html

Banque du Liban - BDL. (2011a, April 21). Intermediate Decision No 10708 of April 21, 2011, amending Basic Decision No 9382 of July 26, 2006 on Corporate Governance, attached to Basic Circular No 106. Intermediate Circular No 255. Retrieved March 12, 2021, from http://www.bdl.gov.lb/circulars/intermediary/5/37/0/Intermediate-Circulars.html

Banque du Liban - BDL. (2011b, April 21). Intermediate Decision No 10707 of April 21, 2011 amending Basic Decision No 7737 of December 15, 2000 (Internal Control in Banks) attached to Basic Circular No 77. Intermediate Circular No 254. Retrieved March 12, 2021, from http://www.bdl.gov.lb/circulars/intermediary/5/37/0/Intermediate-Circulars.html

Banque du Liban-BDL. (2021).Committees \& Commissions. Retrieved March 21, 2021, from https://bdl.gov.lb/tabs/index/1/141/Committees-\&-Commissions.html

Bryman, A., \& Bell, E. (2011). Business Research Methods, $3^{\text {rd }}$ edition. Oxford: Oxford University Press/Online Resource Centre. Retrieved March 21, 2021, from https://www.uwcentre.ac.cn/haut/wp-content/uploads/2018/11/Alan_Bryman_Emma_Bell_Business_Resea rch_Methodsb-ok.cc.pdf

Bucur, C. R. (2012). The Globalisation of the Banking Sector - Evolutions and Predictions. Economic Insights Trends and Challenges, $\operatorname{LXIV(1),73-81.}$

Burns, R. B., \& Burns, R. A. (2008). Business research methods and statistics using SPSS. London: SAGE Publications.

Carozza, D. (2007, May/June). An Interview with Sen. Paul S. Sarbanes: Sarbanes-Oxley Act Revisited. Fraud Magazine. Retrieved March 23, 2021, from http://www.fraud-magazine.com/article. aspx ?id=442

Center for International Private Enterprise (CIPE). (2021). Who we are. Retrieved March 12, 2021, from https://www.cipe.org/who-we-are/

Chehimi, G. M., Hejase, A. J., \& Hejase, N. H. (2019). An Assessment of Lebanese Companies' Motivators to Adopt CSR Strategies. Open Journal of Business and Management, 7, 1891-1925. 
https://doi.org/10.4236/ojbm.2019.74130

Claessens, S. (2003). Corporate Governance and Development. Global Corporate Governance Forum, Focus 1. Washington, DC, USA: The International Bank for Reconstruction and Development/The World Bank. $\begin{array}{llll}\text { Retrieved April } & 12, & 2021, & \text { from }\end{array}$ https://www.researchgate.net/publication/5217975_Corporate_Governance_and_Development

Claessens, S., \& Kodres, L. (2014, March). The Regulatory Responses to the Global Financial Crisis: Some Uncomfortable Questions. IMF Working paper WP/14/46, International Monetary Fund. Retrieved February 21, 2021, from https://www.imf.org/external/pubs/ft/wp/2014/wp1446.pdf

Claessens, S., \& Yurtoglu, B. (2012). Corporate Governance and Development - An Update. Global Corporate Governance Forum Focus 10. Washington, DC, USA: The International Finance Corporation. Retrieved $\begin{array}{lll}\text { March 23, 2021, from } & \text { 23, }\end{array}$ https:/www.ifc.org/wps/wcm/connect/15fae179-97e0-48ea-a123-abc07deabd36/Focus10_CG\%26Develop ment.pdf?MOD=AJPERES\&CVID=jtCwukM

Collins, H. (2010). Creative Research: The Theory and Practice of Research for the Creative Industries. Switzerland: AVA Publications.

Corporate Finance Institute - CFI. (2021b). Basel III: The global regulatory framework for banks. Retrieved March 21, 2021, from https://corporatefinanceinstitute.com/resources/knowledge/finance/basel-iii/

Corporate Finance Institute. (2021c). Major Risks for Banks. Retrieved March 21, 2021, from https://corporatefinanceinstitute.com/resources/knowledge/finance/major-risks-for-banks/

Corporate Finance Institute-CFI. (2021). Basel II. Retrieved February 22, 2021, from https://corporatefinanceinstitute.com/resources/knowledge/finance/basel-ii/

Corporate Finance Institute-CFI. (2021a). What is Basel II? Retrieved March 12, 2021, from https://corporatefinanceinstitute.com/resources/knowledge/finance/basel-ii/

Credit Bank. (2018, July 16). Credit Bank’s Guide to Corporate Governance. Retrieved April 20, 2021, from http://www.creditbank.com/CorporateGovernance/CodeofCorporateGovernance.aspx

Crowther, D., \& Lancaster, G. (2008). Research Methods: A Concise Introduction to Research in Management and Business Consultancy (2nd ed.). Oxford, UK: Butterworth-Heinemann.

Dahya, J., McConnell, J. J., \& Travlos, N. G. (2002). The Cadbury Committee, Corporate Performance, and Top Management Turnover. The Journal of Finance, 57(1), 461-483. https://doi.org/10.1111/1540-6261.00428

DeFranzo, S. E. (2011, September 21). What is the Difference between Qualitative Research and Quantitative Research? Retrieved March $\quad 21, \quad$ 2021, from http://www.snapsurveys.com/blog/what-is-the-difference-between-qualitative-research-and-quantitative-research/

Dudovskiy, J. (n.d.). Positivism. Retrieved February 22, 2021, from http://research-methodology.net/research-philosophy/positivism/

Elo, S., \& Helvi, K. (2008). The qualitative content analysis process. Journal of Advanced Nursing, 62(1), 107-115.

Ersel, H. (2011, May 23). Basel I and Basel II: History of an Evolution [PowerPoint slides]. National Research University Higher School of Economics, Russia.

Federal Reserve. (2016, December 2). Supervisory Policy and Guidance Topics: Credit Risk Management. Retrieved November 12, 2016, from https://www.federalreserve.gov/supervisionreg/topics/credit_risk.htm

Financial Reporting Council (FRC). (2012, September). The UK Corporate Governance Code. Report UP/FRC-BI12001, London: The Financial Reporting Council Limited. Retrieved March 8, 2021, from https:/www.frc.org.uk/getattachment/e322c20a-1181-4ac8-a3d3-1fcfbcea7914/UK-Corporate-GovernanceCode-(September-2012).pdf

Finger, H., \& Sdralevich, C. (2009, August 11). IMF Survey: Resilient Lebanon Defies Odds In Face of Global Crisis. IMF Middle East and Central Asia Department. Retrieved March 21, 2021, from https://www.imf.org/en/News/Articles/2015/09/28/04/53/socar081109a

Hamad, T. (2009). Corporate governance and the financial crisis. Eygpt: Dar Algamiaye.

Han, Pliny (Ed.) (2011, August 5). Guidelines on Corporate Governance of Commercial Banks. Consultative Document. China Banking Regulatory Commission. Retrieved April 20, 2021, from http://english1.english.gov.cn/2011-08/05/content_1920324.htm 
Hartman, F., \& Slapničar, S. (2007). Characteristics of internal management control systems in Slovenian banks. $\begin{array}{llll}\text { Retrieved } \quad \text { March } & 21, & 2021, & \text { from }\end{array}$ https://silo.tips/download/corporate-governance-in-banks-characteristics-of-internal-management-control-sys

Harvard Kennedy School (HKS). (2002, October 8). Financial Oversight of Enron: The SEC and Private-Sector Watchdogs. Report of the Staff to the Senate Committee on Governmental Affairs. Retrieved April 2, 2021 , from https://www.govinfo.gov/content/pkg/CPRT-107SPRT82147/pdf/CPRT-107SPRT82147.pdf

Hejase, A. J., \& Hejase, H. J. (2013). Research Methods: A Practical Approach for Business Students (2nd ed.). Philadelphia, PA: Masadir Inc.

Hejase, H. J., Hejase, A. J., \& Hejase, H. A. N. J. (2012). Quantitative methods for decision makers: Management approach. Beirut, Lebanon: Dar Sader Publishers.

Hoskisson, R., Eden, L., Ming Lau, C., \& Wright, M. (2000). Strategy in Emerging Economies. Academy of Management Journal, 43(3), 249-267.

International Finance Corporation - IFC. (2014, January). Corporate Governance: Overview. Retrieved February 12, 2016, from http://www.ifc.org/wps/wcm/connect/Topics_Ext_Content/IFC_External_Corporate_Site/IFC+CG

International Finance Corporation-IFC. (2015, February). Corporate Governance: Background. Retrieved March 21, 2021, from https://www.ifc.org/wps/wcm/connect/a7913e32-7225-4850-9438-3b8688557788/CG+LAC+Program+Fact + Sheet.pdf?MOD=AJPERES\&CVID=kMUEOwt

International Monetary Fund - IMF. (2019). Basel Capital and Liquidity

King, M. J. (2010). Back Office and Operational Risk: Symptoms, Sources, and Cures. UK: Harriman House Limited.

Kothari, C. R. (2004). Research Methodology. Methods and Technique, (2nd ed.). New Age International Publishers.

Laeven, L., \& Ratnovski, L. (2014, July 21). Corporate governance of banks and financial stability. Retrieved March 5, 2021, from http://voxeu.org/article/corporate-governance-banks-and-financial-stability

Levrau, A., \& Van Den Berghe, L. (2007). Identifying key determinants of effective boards of directors. Vlerick Leuven Gent Working Paper Series, Vlerick Leuven Gent Management School 11, 1-58. Retrieved March 21, 2021, from https://www.researchgate.net/publication/23646760_Identifying_key_determinants_of_effective_boards_of _directors

Lewis, S. (2019). Corporate governance. Tech Target. Retrieved March 21, 2021, from https://searchcompliance.techtarget.com/definition/corporate-governance

Lipton, M., Neff, D. A., \& Brownstein, A. R. (2019, November 20). Risk Management and the Board of Directors. Wachtell, Lipton, Rosen \& Katz Law Firm. Retrieved March 21, 2021, from https://corpgov.law.harvard.edu/2019/11/20/risk-management-and-the-board-of-directors-7/

Marcinkowska, M. (2012). Corporate Governance in Banks: problems and Remedies. Financial Assets and Investment, 2, 47-67. https://doi.org/10.5817/FAI2012-2-4

Mehran, H., Morrison, A., \& Shapiro, J. (2011). Corporate Governance and Banks: What Have We Learned from the Financial Crisis?. Staff Report no. 502 June 2011, Federal Reserve Bank of New York Staff $\begin{array}{lllll}\text { Reports. } & \text { Retrieved } & \text { April } & 20, & \text { from }\end{array}$ https://www.newyorkfed.org/medialibrary/media/research/staff_reports/sr502.pdf

Mehta, C. R., \& Patel, N. R. (2012). IBM SPSS Exact Tests. Retrieved February 22, 2021, from http://www.sussex.ac.uk/its/pdfs/SPSS_Exact_Tests_21.pdf

Middle East \& Africa Bank -MEAB. (2019). History. MEAB [Blog)]. Retrieved February 22, 2021, from https://www.meabank.com/about/history

Monthly. (2018, September 4). Lebanon's banking sector in numbers. Information International. Retrieved February 28, 2021, from https://monthlymagazine.com/article-desc_4784_

Namazi, M. (2013, July). Role of the agency theory in implementing management's control. Journal of Accounting and Taxation, 5(2), 38-47. https://doi.org/10.5897/JAT11.032

Namoga, M. O. (2010). Board Composition, Board Process and Board Performance: Empirical Evidence from 
Pacific Island Countries. Asia Pacific Journal of Accounting and Finance, 1(1), 17-50.

Nasser, W. (2008). Governance in Lebanon comparative study between the private and public sector. Beirut.

Ng, David (2006). The Impact of Corruption on Financial Markets. Managerial Finance, 32(10), 822-836. https://doi.org/10.1108/03074350710688314

Nurhidayat, R. M., \& Rokhim, R. (2018). Corruption and Government Intervention on Bank Risk-Taking: Cases of Asian Countries. Jurnal Dinamika Manajemen, 9(2), 228-237. Retrieved from http://jdm.unnes.ac.id

Oberoi, M. (2019, October 29). Bank Risks: Everything You Need to Know. Retrieved March 21, 2021, from https://marketrealist.com/2019/10/bank-risks-everything-you-need-to-know/

OECD. (2015). G20/OECD Principles of Corporate Governance. OECD Publishing, Paris. https://doi.org/10.1787/9789264236882-en

Palestine Monetary Authority-PMA. (2014). Rules and best practices for corporate governance of banking Palestine Directory. Retrieved March 21, 2021, from https://www.pma.ps/en/Media/Press-Releases/pma-issues-guide-to-corporate-governance-for-bank-rules-an d-best-practices

Romero, S., \& Atlas, R. D. (2002). WorldCom's Collapse: the Overview; WorldCom Files for Bankruptcy; Largest U.S. Case, The New York Times, July 22, 2002.

Saunders, M., Lewis, P., \& Thornhill, A. (2009). Research Methods for Business Students. New York: Pearson Education.

Shier, R. (2004). Statistics: 1.3 The Chi-squared test for two-way tables. Retrieved February 21, 2021, from http://www.statstutor.ac.uk/resources/uploaded/chis-quared-tests-of-association.pdf

Skinner, J., Edwards, A., \& Corbett, B. (2015). Research Methods for Sports Management. New York, NY: Routledge.

Sleiman, M. (2009). Corporate governance in dealing with financial and administrative corruption. Eygpt: Dar Al Jamiaye.

Snieder, R., \& Larner, K. (2009). The Art of Being a Scientist: A Guide for Graduate Students and their Mentors (1st ed.). Cambridge, UK: Cambridge University Press.

Standards for Deposit Takers. In Financial Soundness Indicators Compilation Guide 2019. https://doi.org/10.5089/9781484396209.069.ch003

Telekom Malaysia - TM. (2014). Statement on Corporate Governance. Berhad Annual Report 2014. Retrieved March 21, 2021, from https://www.tm.com.my/AboutTM/CorporateInformation/CorporateGovernance/Documents/2014\%20State ment $\% 20$ on\%20Corporate\%20Governance.pdf

The Institute of Chartered Accountants In England and Wales (ICAEW). (2016). What is corporate governance?. Retrieved March 21, 2021, from http://www.icaew.com/en/technical/corporate-governance/overview/does-corporate-governance-matter

Williams, C. (2007). Research Methods. Journal of Business \& Economics Research (JBER), 5(3). https://doi.org/10.19030/jber.v5i3.2532

Wilson, J. (2010). Essentials of Business Research: A Guide to Doing Your Research Project. SAGE Publications. Thousand Oaks, CA: SAGE Publications Inc.

\section{Copyrights}

Copyright for this article is retained by the author(s), with first publication rights granted to the journal.

This is an open-access article distributed under the terms and conditions of the Creative Commons Attribution license (http://creativecommons.org/licenses/by/4.0/). 